Wilfrid Laurier University

Scholars Commons @ Laurier

Archaeology and Heritage Studies Faculty

Publications

Archaeology and Heritage Studies

2000

\title{
A Moabite Sanctuary at Khirbat al-Mudayna
}

P.M. Michèle Daviau

Wilfrid Laurier University, mdaviau@wlu.ca

Margreet Steiner

University of Leiden

Follow this and additional works at: https://scholars.wlu.ca/arch_faculty

\section{Recommended Citation}

Daviau, P.M. Michèle and Steiner, Margreet, "A Moabite Sanctuary at Khirbat al-Mudayna" (2000). Archaeology and Heritage Studies Faculty Publications. 2.

https://scholars.wlu.ca/arch_faculty/2

This Article is brought to you for free and open access by the Archaeology and Heritage Studies at Scholars Commons @ Laurier. It has been accepted for inclusion in Archaeology and Heritage Studies Faculty Publications by an authorized administrator of Scholars Commons @ Laurier. For more information, please contact scholarscommons@wlu.ca. 


\title{
A Moabite Sanctuary at Khirbat al-Mudayna
}

\author{
P. M. Michèle Daviau \\ Department of Archeology \\ and Classical Studies \\ Wilfrid Laurier University \\ 202 Regina Street, Room 104 \\ Waterloo, ON Canada N2L 3C5 \\ mdaviau@wlu.ca
}

\author{
Margreet Steiner \\ Faculty of Archaeology \\ University of Leiden \\ P. O. Box 9515 \\ 2300 RA Leiden, Holland \\ msteiner@freeler.nl
}

\begin{abstract}
The discovery at Khirbat al-Mudayna on the Wadi ath-Thamad of a small temple within a walled town in central Jordan is a first for ancient Moab. This building, identified as a sanctuary on the basis of its plastered benches and limestone altars, is not a national temple with direct access entry. Rather, it is a local sanctuary, with indirect access from an alleyway that runs parallel to the south wall of the innermost room of the six-chambered gate. This paper includes a report on Sanctuary 149, excavated during the 1999 season. Of greatest interest are the three stone altars; two are painted, and one is also inscribed. These altars, each of a different type, suggest the range of cultic activities practiced in such a temple. Due to its position adjacent to the gate and to its construction history, the sanctuary probably dates to the early eighth century B.C.
\end{abstract}

\section{INTRODUCTION}

A rtifacts and buildings that defy immediate identification have often been classed as "cultic" with the result that many archaeologists are now leery of assigning religious meaning to finds whose functional classification is uncertain. This was not the case at Khirbat al-Mudayna in 1999, when two clearly recognizable limestone altars and a tall conical altar were found in situ in a room with benches, lamps, and specialized artifacts. Although unique in almost all respects, the altars were identified by analogy with stone altars known from Megiddo (May 1935: pl. 12), Arad (Aharoni 1968), and Miqne (Gitin 1992). This paper consists of a preliminary report on the discovery of Sanctuary 149, the classification of its artifacts and ceramic vessels, and their distribution in the sanctuary. The inscribed label on incense altar MT-4/015 was studied by P.-E. Dion, and the editio princeps of this altar and its inscription is published separately (Dion and Daviau 2000).

\section{EXCAVATION HISTORY}

Khirbat al-Mudayna on the Wadi ath-Thamad, located $20 \mathrm{~km}$ southeast of Madaba (fig. 1), is a town site with occupation dating to the Iron Age II (ca. $800-700$ B.C.). Excavation began in 1996 at the north end of the mound, where a six-chambered gate (Building 100) was revealed during four seasons of excavation (Daviau 1997; in press b). Inside the town, south of the gate, is an open courtyard (C150; fig. 2) that was found to contain animal bones and zoomorphic ceramic figurines. ${ }^{1}$ Only in 1999 did it become clear that the courtyard does not extend east into the area directly south of the eastern row of gate rooms. Instead, immediately south of Gate Room 103 and parallel to its southern wall (W1005) is a staircase

\footnotetext{
${ }^{1}$ Initial study by P. Popkin of $2500+$ bones from Squares A8 and A9 indicates that there were cut marks or slaughtering marks on the bones. Further excavation in Courtyard 150 is planned for 2001 in view of the discovery, at the end of the 1999 season, of a lower surface.
} 


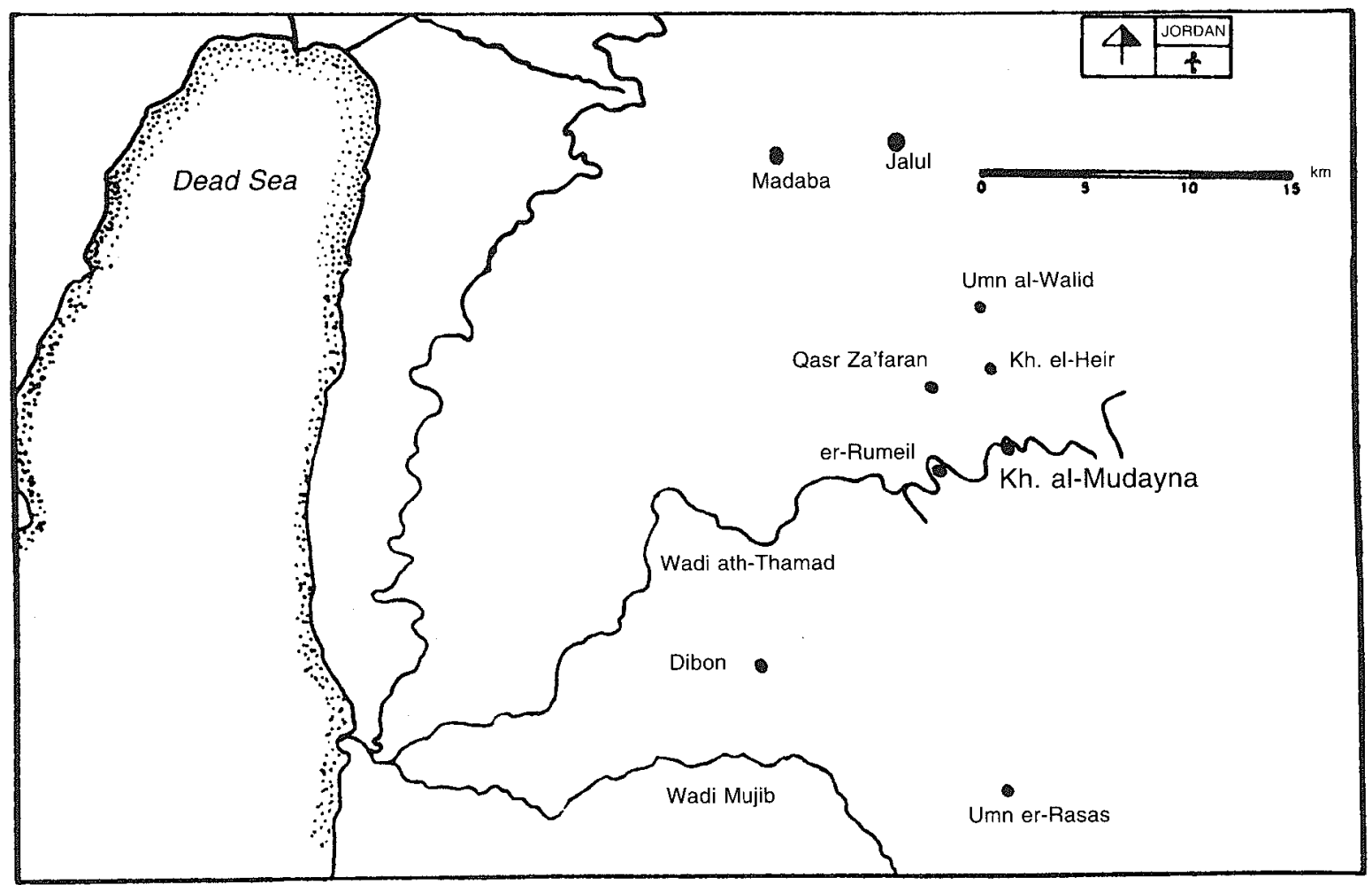

Fig. 1. Map of northern Moab, including Dibon, Khirbat al-Mudayna, and Madaba.

(S105), which leads from the central street to the upper-storey rooms over the gate. Parallel to the staircase is an alleyway (S109), and to the south of that is the small sanctuary, Building 149 (fig. 3). The position of a doorway off of Alleyway S109, instead of directly from Courtyard 150 on the west, forms an indirect entrance into Building 149. This traffic pattern suggests that this structure functioned as a modest sanctuary rather than a full-fledged temple. However, the final characterization of Building 149 awaits further excavation and analysis.

\section{ALLEYWAY S109}

The area between Staircase Wall 1032 and the north wall (W1033) of Building 149 can be interpreted as an alleyway running east from Street $104 .^{2}$ This passageway (S109) is only about $1.00 \mathrm{~m}$ wide and serves to connect Courtyard 150 with a second alleyway (S107) that runs north-south along the

\footnotetext{
${ }^{2}$ Excavation was carried out by J. Radine and E. Maly.
}

west face of the inner casemate wall (W2002; fig. 2). From the eastern edge of Doorway P, Wall 1033 runs east for a length of $4.35 \mathrm{~m}$ and abuts the inner casemate wall (W2002) against its west face. ${ }^{3}$ The western jamb of Doorway P, comprising Wall 1034 (=A17:10), continues the line of Wall 1033 to the west and bonds with the north-south Wall 1036 (= A17:11/36), which forms the west wall of Sanctuary 149. In Alleyway S109, Surface A17:25, the principal floor in use during the final use phase of Sanctuary 149 , consists of hard-packed beaten earth with

\footnotetext{
${ }^{3}$ The extension of Wall 1033 as far east as Inner Casemate Wall 2002 cut off access from Alleyway 109 to the alleyway's continuation to the south. Inside Building 149 and south of Wall 1033, the west wall of this extension of Alleyway 109 can be seen beneath the floor (A27:9), indicating clearly its sequence in the stratigraphic phases of construction south of Gate Complex 100. Excavation of this earlier phase, and the search for a doorway through Wall 1033, is planned for the next field season. At this stage, we can only assume that the original design of the town included an alleyway along the inner face of the inner casemate wall.
} 


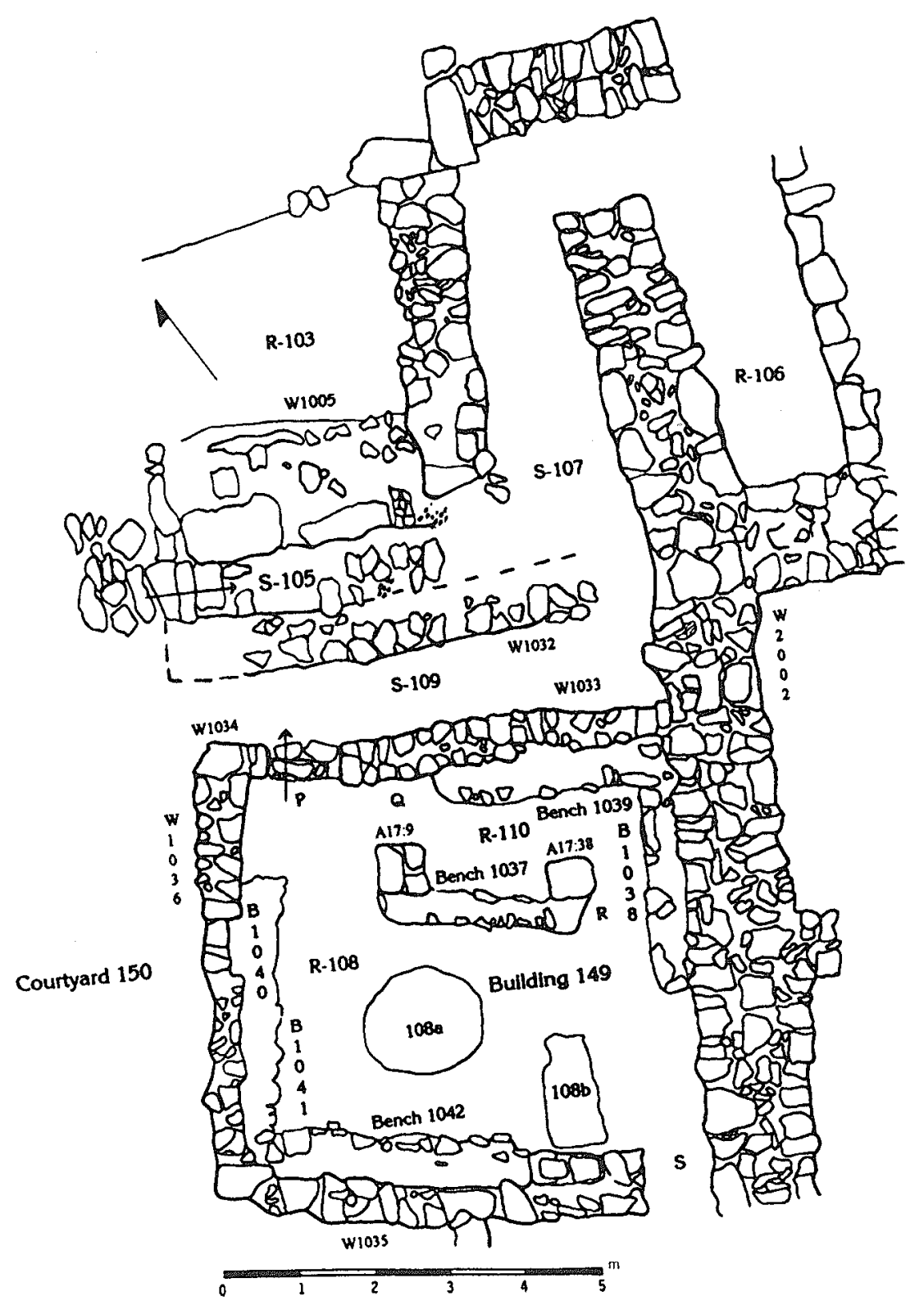

Fig. 2. Plan of Building 149, Alleyway 109, Stairway 105, Gate Room 103, Alleyway 107, and Casemate Room 106.

ashy patches. This floor is at the level of the uppermost step (A17:76) in Doorway $\mathrm{P}$ that leads down into Building 149.

BUILDING 149

Building 149 is located approximately $2.50 \mathrm{~m}$ south of Gate Room 103 (in Squares A17, A18, and
A27; fig. 2). ${ }^{4}$ The sanctuary consists of one large room $(5.50 \times 5.50 \mathrm{~m})$ divided by a bench into a main

\footnotetext{
${ }^{4}$ M. Steiner was field supervisor of Squares A17-18, A26-27. Square supervisors in the sanctuary were P. Popkin (A17-18) and G. Gohm (A27). In order to control recording of loci and pottery pails in Square A17, only even numbers were used in Rooms 108 and 110. Odd numbers were used
} 


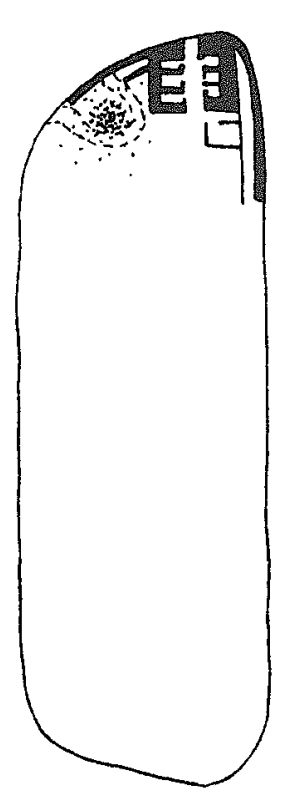

Fig. 3. Sketch plan of position of Building 149, south of Gate 100.

room (R108) and an annex (R110) on the northeast (fig. 4). Initial excavation in Square A18 suggests a possible adjoining room to the south (see below). The inner casemate wall (W2002 = A27:3) forms the eastern wall of both Rooms 108 and 110. This wall (W2002) is constructed of medium-size limestone boulders, three rows thick. The walls on the north (W1033), west (W1036), and south (W1035) are, for the most part, two rows wide, built of small boulders and large cobbles in boulder-and-chink construction. At present, the rows and courses are quite irregular, and the wall lines are not perfectly straight.

Running alongside each wall is a bench. These benches are constructed of two or three courses of cobbles and small boulders with a filling of packed mud. They are two rows deep $(0.35-0.55 \mathrm{~m})$ and are plastered both on top and on the sides. In all cases, the plaster on top of the bench sealed against the face of the wall. The tops of the benches are all in the range of $0.30-0.40 \mathrm{~m}$ above floor level.

The benches do not cover the full length of the walls, so the northwest and southeast corners are left free. In the northwest corner is Doorway P into Alleyway 109. In this doorway are two stone-built

in Alleyway 109 and Stairway 105, beginning with locus number A17:15. Note: In our recording system, A17:15 equals Field A, Square 17, Locus 15. In certain instances, a feature may be found in more than one area of the square, each with its own number, or in more than one square. steps (A17:76) that lead up to the level of Alleyway 109. The rise between each step is 0.11 to $0.12 \mathrm{~m}$ in height. It seems probable that a similar doorway ( $S=A 27: 14$ ) in the southeastern corner of Room 108 (between the east end of Wall 1035 and the west face of Inner Casemate Wall 2002) led into a second room south of the sanctuary proper. ${ }^{5}$ In view of the position of these doorways, the bench (1038 = A27:6) that lines east Wall 2002 begins $2.00 \mathrm{~m}$ north of the southeast corner and runs north to the northeast corner (in R110) for a length of $2.80 \mathrm{~m}$. In the northeast corner, Bench 1038 abuts Bench 1039 (=A17:30 + A27:5), which runs along the south face of north Wall 1033 for a length of $3.20 \mathrm{~m}$, ending 1.20 m east of Doorway P. ${ }^{6}$ A similar pattern is seen in the position of the benches along the south and west walls. Bench 1042 extends west $5.05 \mathrm{~m}$ along south Wall 1035 and forms a corner with Bench 1041, which in turn runs $2.55 \mathrm{~m}$ north along the east face of west Wall 1036. At this point, Bench 1041 abuts the south edge of a low platform (1040) that filled a niche in Wall 1036. Both the bench (B1041) and the platform (B1040) that filled the niche are coated with light gray (10YR 7/2) plaster, which also extends up the eastern face of Wall 1036.

Another bench (1037) is free standing; it runs $2.75 \mathrm{~m}$ east-west between two large composite stone pillars (A17:9, A17:38) located in the northern part of Room 108 and marks the division between Rooms 108 and 110 . This bench is also formed of one to two rows of large cobble-size limestone field stones and measures $0.40-0.50 \mathrm{~m}$ deep. Bench 1037 is three courses high and stands $0.37-0.40 \mathrm{~m}$ above the floor surface. Like the other benches, it is coated with reddish-yellow mud brick material and is sealed on its north face with white plaster (A17:24, 10YR 8/2). This same plaster seals up against the south and west faces of Pillar A17:38 and the south and east faces of Pillar A17:9. The evidence from a probe up against the west face of Pillar A17:38 revealed several layers of plaster, indicating careful maintenance of Building 149.

\footnotetext{
${ }^{5}$ This is the more likely as the northernmost stone of wall line A18:3 seems to bond with Wall 1035. If this stone is, in fact, part of a wall, then Building 149 may have consisted of two or three rooms.

${ }^{6}$ Bench 1038 was coated on both its upper surface and its side with a layer of very pale brown (10YR 8/3) plaster $(\mathrm{A} 17: 44=\mathrm{A} 27: 12)$; Bench 1038 was likewise covered with plaster (A27:13).
} 


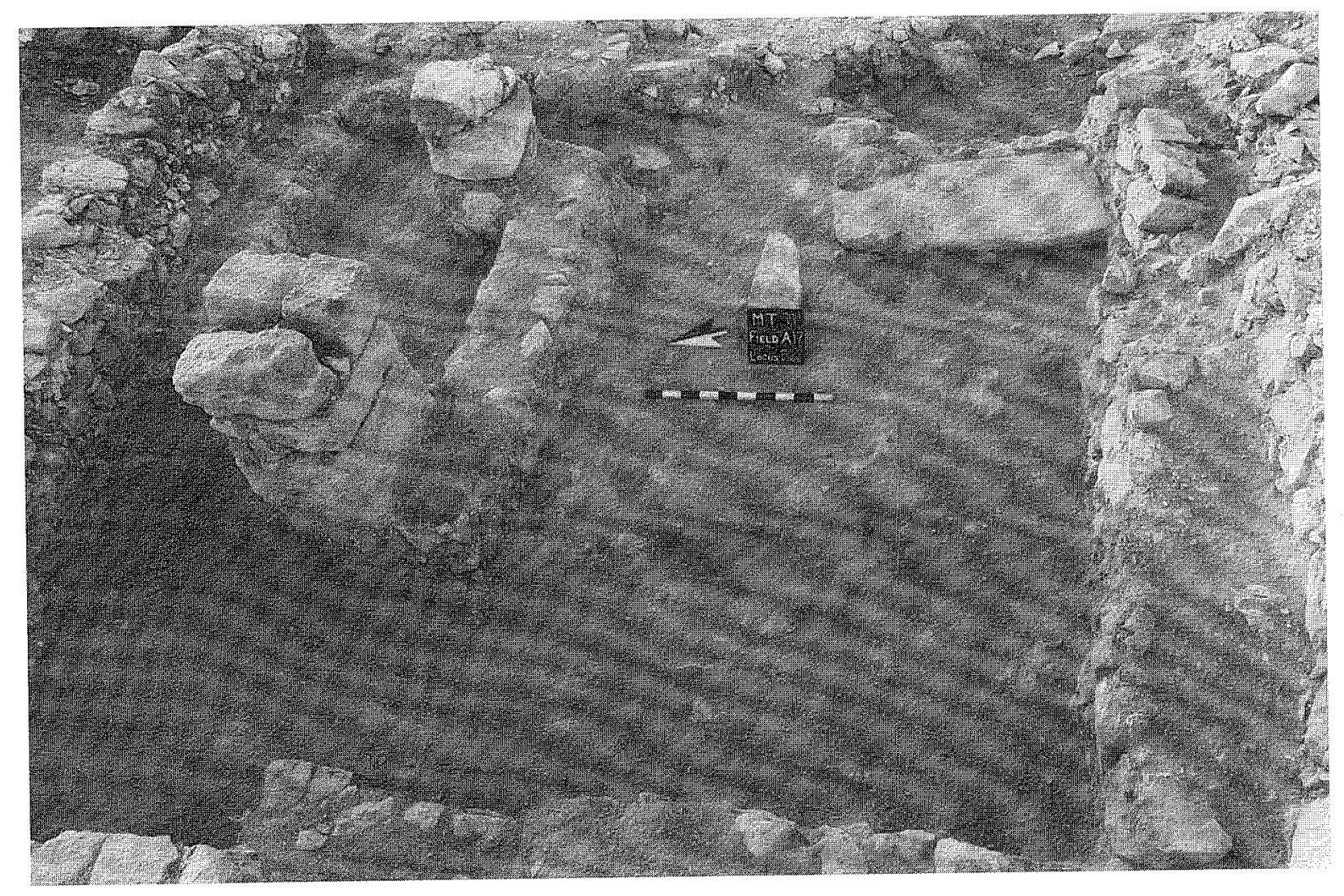

Fig. 4. Building 149, looking east (Photo by R. Chadwick).

The pillars themselves are of much better construction than the walls of the sanctuary. For example, Pillar A17:9 is constructed of a large, almost square stone $(0.69 \times 0.59 \times 0.82 \mathrm{~m}$ high $)$ with two upper courses of smaller stones in header-and-stretcher technique for a total height above floor level of 1.38 $1.42 \mathrm{~m}$. Pillar A17:38 is slightly smaller $(0.58 \times 0.53$ $\times 1.05-1.10 \mathrm{~m} \mathrm{high}$ ), but is also formed of hewn boulders. $^{7}$ Each pillar probably acted as a ceiling support as well as forming the frame of a doorway into Area R110: Pillar A17:9 was the south frame of Doorway Q, while the south face of Wall 1033 was the north frame. Evidence that this entryway was deliberately designed can be seen in the position of Bench A17:30, which ends just east of the eastern edge of Pillar A17:9, leaving the doorway open the full width of the room. On the east, Pillar A17:38 forms the west edge of Doorway R, while the eastern

\footnotetext{
${ }^{7}$ Both pillars were founded on an earlier floor level (A 17:68) identified in a probe through Floor A17:54; Pillar A 17:9 probably had an original height of $1.75-1.80 \mathrm{~m}$.
}

edge of the doorway consists of the western edge of Bench 1038.

The floor surface $(\mathrm{A} 17: 54+66,56+\mathrm{A} 27: 9)$ in Sanctuary 149 consists of hard-packed beaten earth with lumps of brick material. In some areas, a very thin burnt layer was found on top of the surface, but we found no real ash or charcoal layers. The floor surface is very uneven, possibly because the heavy rockfall above it caused significant damage; but the whole building is admittedly of slight and irregular construction. The floor surface in Room 110 was cut through in a probe and was shown to be approximately $0.25 \mathrm{~m}$ thick. Also visible in the probe was the relationship of the surface to Bench 1039; the bench appears to have been built at the same time as the floor surface (A17:54,56), which in turn sealed against it. This construction technique was probably used for the remaining benches as well.

\section{The Installations of R110}

In the northeastern sector of the sanctuary, there are two distinct activity areas in Room 110. The first 


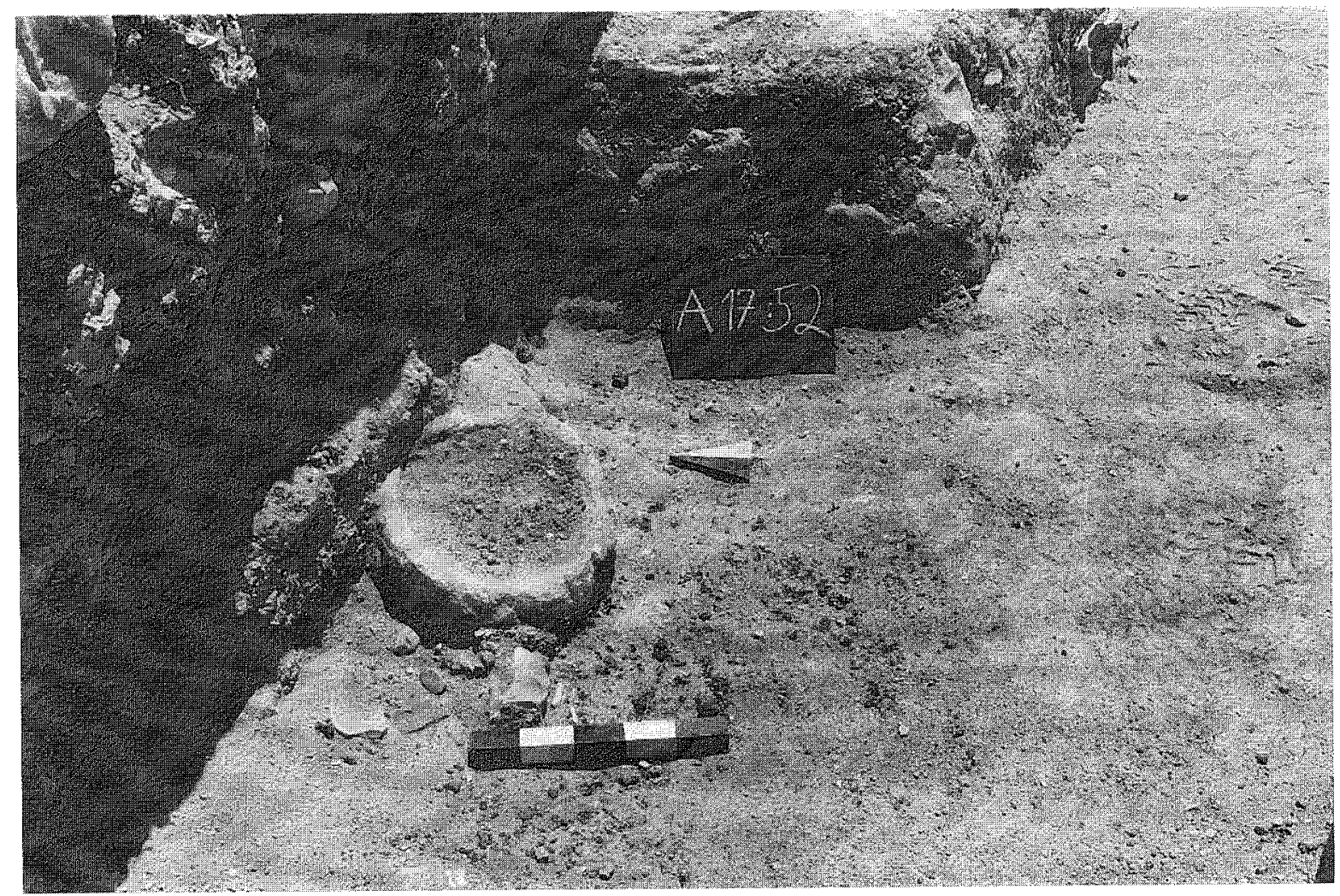

Fig. 5. Mortar bowl MT-4/018 on bed of iron fragments (Photo by P. M. M. Daviau).

area is located adjacent to the west end of Bench 1039, east of Doorway P, and north of Pillar A17:9 (fig. 2). Here, in Entrance Q, we found a concentration of ash and charcoal (A17:52) on Surface A17: $54=66$. Along with the lumps of charcoal, we found animal bones, lithics, and lumps of iron, which seem to be smithing slag. ${ }^{8}$ A limestone boulder mortar (MT-4/018 $=$ MT-397 $)^{9}$ was found in situ on top of Ash Layer A17:52 (fig. 5). Inverted above the boulder mortar was a small rectangular limestone basin

\footnotetext{
${ }^{8}$ Xander Veldhuijzen, University of Leiden, conducted a preliminary analysis of the metal samples.

${ }^{9}$ All finds were assigned a sample number in the range 390-590. Of these finds, artifacts recovered during this fourth season at Khirbat al-Mudayna were registered as MT-4/001-4/029. The full registration number recorded on each sample includes its field, square, pottery pail, and sample number (A17.74.397). S. Feltham and J. Fletchall prepared the artifact drawings in the field; S. Feltham prepared the final inked illustrations.
}

or trough (MT-4/016 = A17:50.395), which measures $0.43 \times 0.26 \times 0.18 \mathrm{~m}$ in height. To the east of this trough, probably fallen from the west end of Bench 1039, was a gaming board (MT-4/017 = A17.72.396; see fig. 6 for position of gaming board). Underneath ash concentration A27:52, the surface (A17:66) consisted of very hard packed earth and small cobbles. ${ }^{10}$ The position of these objects in the space between Pillar A17:9 and the north wall (W1033) of Building 149 impeded easy access to Area R110 since the boulder mortar reduced the already narrow width $(0.80 \mathrm{~m})$ of the entrance (Doorway $\mathrm{Q}$ ).

The second activity area is located in the space between Benches 1037 and 1039, north and east of Pillar A17:38. Finds in this area of Room 110 include

\footnotetext{
${ }^{10}$ Although there was not extensive evidence for burning, Surface A17:66 (10YR 7/3, very pale brown) may have been hardened by heat associated with the lumps of slag which in turn suggest smithing.
} 


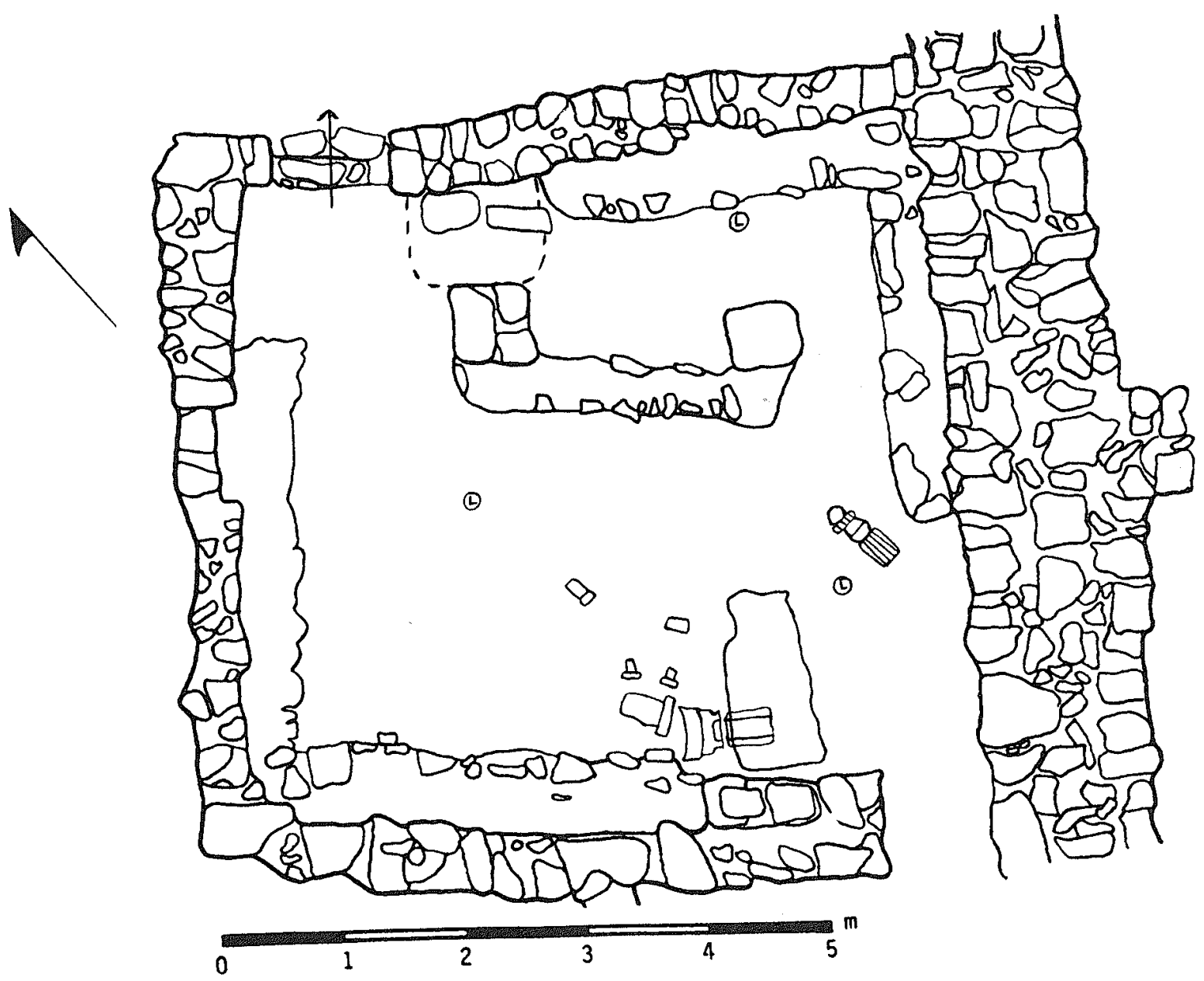

Fig. 6. Altars, lamps, and podium stone 108b on floor of Sanctuary 149.

a late Iron Age II lamp (V105), located in debris layer A17:7 (above Surface A17:9), a fragment of iron slag, and a ceramic leg fragment (A17:80.540), possibly from a zoomorphic figurine. The position of Pillar A17:38 at a distance of $0.70 \mathrm{~m}$ west of Bench 1038 allows for a doorway (R) between subsidiary Room 110 and the main sanctuary room (R108).

\section{The Installations of R108}

In the principal room of the sanctuary, several installations were found on and under the floor surface (A17:56). In the center of R108, a large pit (108a), $1.35-1.55 \mathrm{~m}$ in diameter, had been cut through the floor (fig. 2). Although it was excavated to a depth of about $0.90 \mathrm{~m}$, we did not reach its bottom. In its upper layers, the pit was found to contain ce- ramic sherds from seven distinct vessels, none of which is complete (see below), and a stone with a rectangular depression (Sample \#551); ${ }^{11}$ otherwise finds are few. The pit was clearly in use during the existence of Building 149, because it was cut through Surface A17:56 and resealed by a layer (A17:60) of pale yellow (2.5Y 8/4) plaster. This layer may once have covered the complete surface of the room, because several patches were found in other places and lenses of ash (A17:22, 48) extended over both the yellow surface and over the original floor (A17:56). Objects in the temple during its final use phase had

\footnotetext{
${ }^{11}$ This limestone block has a rectangular depression on one end that suggests its use as a mold for the manufacture of metal tools.
} 
fallen onto this plaster layer, indicating clearly the stratigraphic position of the pit.

Immediately west of Doorway $\mathrm{S}$ in the southeastern corner of Room 108, a large flat stone (108b $=\mathrm{A} 18: 12$ ), measuring $0.75 \times 1.50 \mathrm{~m}$ and $0.16 \mathrm{~m}$ thick, was installed on floor Surface A17:56. The upper surface of this stone is smoothly polished, and the stone itself is different from the limestone used in wall construction. Along its eastern edge, Stone $108 \mathrm{~b}$ was supported by three stones embedded in the floor, while a thin wall (A18:11) framed its southern end. This wall unit stood on top of the lower stones of Bench 1042, which had been partly cut away to provide space for it. Stone $108 \mathrm{~b}$, the wall, and the bench were sealed by layers of yellowish plaster. Underneath Stone 108b lay a thin layer of soft soil containing a small amount of pottery sherds, animal bones, and charcoal. In its final period of use, Stone $108 \mathrm{~b}$ served as the support or low podium for three altars that had fallen and lay broken in pieces around it. Lying between the broken altars were two limestone objects (pegs?) that were probably used in association with them.

\section{The Stone Altars}

Three free-standing limestone altars and two limestone pegs were located in the debris layers (A18:8, 15,20 ) surrounding Stone $108 \mathrm{~b}$ (fig. 6). While the stone pegs have remained intact (MT-4/012 $=391$, $4 / 013=392$ ), all three altars are broken. Two altars can be described as quadrangular shaft altars, while the third altar has a conical base and a cylindrical stem that supports a bowl. The larger shaft altar (MT-4/011 = A18:9.390) fell with its upper surface toward the west and its trunk lying across Stone 108b (fig. 7). The second altar (MT-4/014 = A18:17.393) lay just to the west with its upper surface facing east. Beneath Altar MT-4/014 were the two limestone pegs in position just above floor Surface A17:56. The third altar is tall, conical in shape (MT-4/015 = 394), and bears an inscription; it is broken into three pieces that were widely scattered in the debris. Two fragments, constituting the upper half, were located 0.75 $m$ north of Altar MT-4/011, with one piece facing west and the top piece facing east. The base of this altar was recovered in the debris (A27:1) south of Doorway R and west of Inner Casemate Wall 2002, just to the northeast of Stone 108b. The position of the three pieces of Altar MT-4/015 suggests that it had been in position on the north end of Stone $108 \mathrm{~b}$ and had been broken by the collapse of Inner Casemate Wall 2002. ${ }^{12}$

The Painted Altar (MT-4/011; figs. 7, 8a, 9a, 9b). Limestone Altar MT-4/011 consists of two large pieces that mend together forming the upper part of a rectangular shaft altar painted on at least one side. The base, now badly broken, was shattered by falling wall stones and has not been recovered. The preserved height of the altar is about 0.72 $0.80 \mathrm{~m},{ }^{13}$ and the shaft is almost square in section $(30.5 \times 34.0 \mathrm{~cm})$ with moldings running vertically along each corner and framing a sunken, central panel. ${ }^{14}$ These corner moldings protrude at a right angle, $2.0-2.5 \mathrm{~cm}$ from each side of the shaft, although they do not extend beyond the upper part or rim of the altar (fig. 9b). ${ }^{15}$ These moldings, like the shaft itself, are finely cut and exceptionally smooth. ${ }^{16}$ The upper third of the altar constitutes the rim which protrudes in two stages, each approximately $3.2-4.0 \mathrm{~cm}$ larger than the one below it. The lower stage is $8.0 \mathrm{~cm}$ tall and the upper stage, or rim proper, is $20.0-21.0 \mathrm{~cm}$ tall. Although there are no true horns on this altar, the upper edges of the rim curve slightly from one corner to another. On each upper edge, it is still possible to see the marks (2-3 mm wide) of the tool used by the stone mason who fashioned this finely made altar.

\footnotetext{
${ }^{12}$ The three altars could easily have stood side by side on Platform Stone 108b. Altogether, the maximum space needed if the altars were placed close together is about $0.90 \mathrm{~m}$, while Stone $108 \mathrm{~b}$ measures $1.50 \mathrm{~m}$ in length.

${ }^{13}$ More accurate dimensions may be possible following attempts at restoration and repair of the altars. Because of the soft chalk from which they were carved, however, the altars may not be able to be fully restored.

${ }^{14}$ The authors are grateful to Dr. Eric Haldenby, Director of the School of Architecture, University of Waterloo (Waterloo, Ontario, Canada), for suggesting terminology to describe the elements of the shaft of Altar MT-4/011.

${ }^{15}$ The terminology used is based on the typology established by Gitin (1989) in order to be able to indicate more clearly the similarities and differences among the altars from Building 149 and 37 altars from sites in ancient Israel, Judah, and Philistia in Gitin's typology.

${ }^{16}$ The fine finishing on Altar MT-4/011 gave us the initial impression of Nabataean or early Roman craftsmanship. It was only the discovery of Altars MT-4/014 and 4/015, the latter with its Iron Age inscription, that led to the identification of Altar MT-4/011 as a product of the Iron Age.
} 


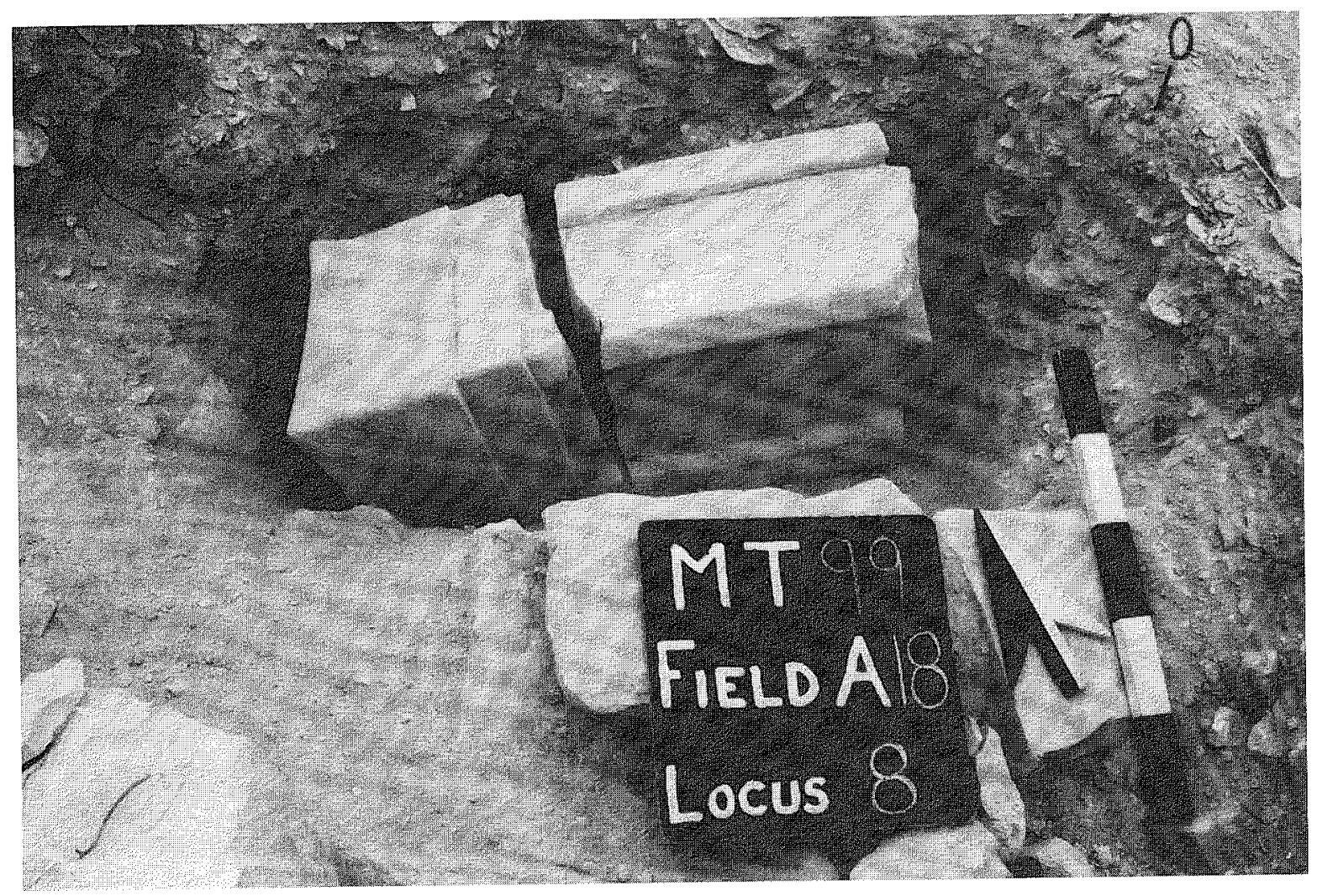

Fig. 7. Painted altar MT-4/011 in situ.

One exterior face of the upper and lower rim sections retains evidence of paint (fig. 8a). Pale red horizontal lines and traces of black paint are still visible along the upper and lower edges of the upper rim section. Somewhat better preserved is a row of triangles, alternately red and black, that fills the register between two red painted horizontal lines. ${ }^{17}$ Along the right edge, a vertical line of red paint runs from the upper to the lower corner of the rim. A second painted symbol, located near the right edge of the lower section of the rim, is even better preserved. Here a red circle is divided into four pie-shaped wedges, two red wedges alternating with two, slightly larger, black ones. Just below this symbol, on the vertical molding itself, is another painted symbol, this time subrectangular in shape. It appears to be primarily black with one faint red triangle in the cen-

\footnotetext{
${ }^{17}$ The front face of Altar MT-4/011 is incomplete, due to a large break on the adjoining side. At the left edge, the corner is missing, probably $2.00-3.00 \mathrm{~cm}$ having broken off. Whether this was enough space for another triangle, this time in black, is unclear from the portion preserved.
}

ter. ${ }^{18}$ Evidence for additional painted decoration is still preserved in short sections of faint red paint along the vertical edge of the painted curb, and in two parallel red lines, $3.50 \mathrm{~cm}$ apart, on one side of the rim. These lines continue those on the front that border the painted triangles, but the space between these lines appears unpainted. No evidence for paint is preserved on the other side or on the back.

Parallels for this style of decoration on stone are difficult to find in current literature, although the designs may have taken their inspiration from patterns in contemporary textiles. ${ }^{19}$ Parallels for the motif of a circle with a cross inside, resulting in four wedges, are found on pottery from Tell Deir ${ }^{\mathrm{A}} \mathrm{Alla}$. At least three sherds have been found, two with this pattern scratched into the surface of a pot before firing. The third one is a fragment of a ring-shaped, hollow

\footnotetext{
${ }^{18}$ The color of the original paint may have been dark blue, although black is more commonly used on ceramic vessels.

${ }^{19}$ Pauline Albenda, personal communication, Nov. 19 , 1999.
} 


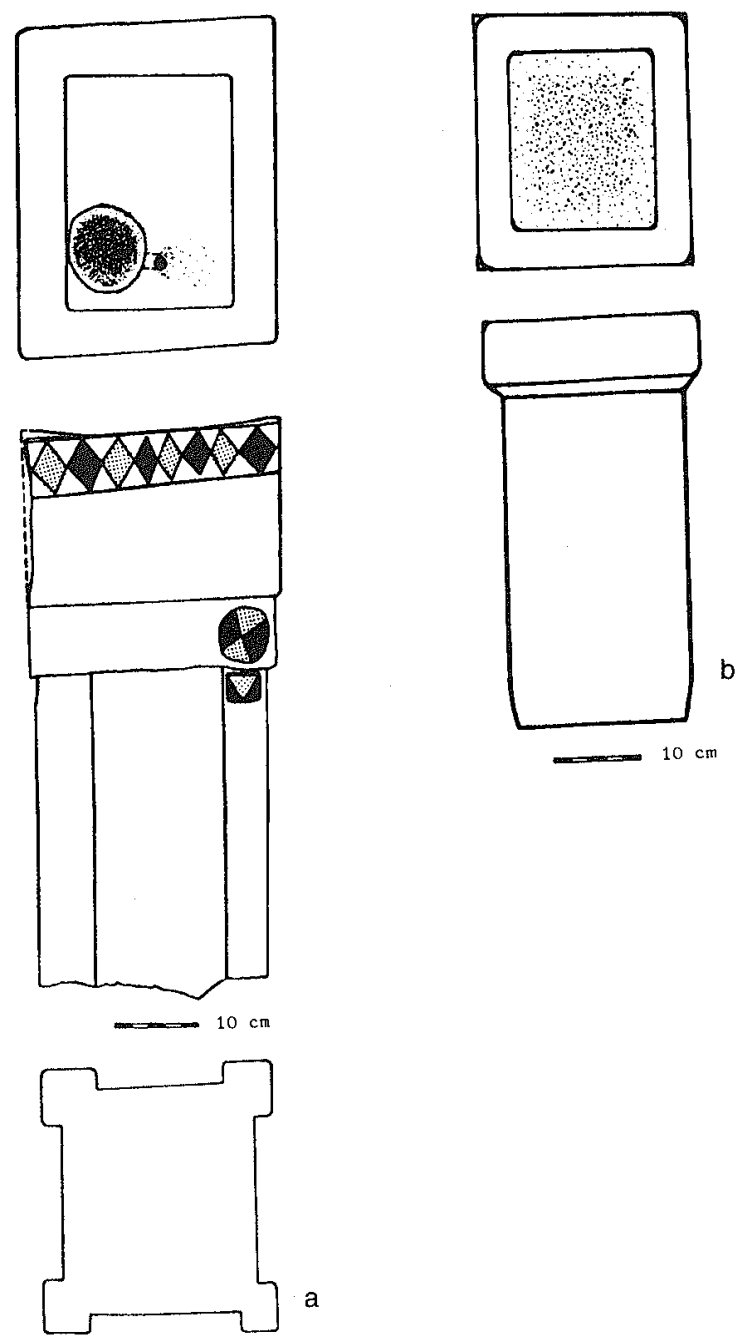

Fig. 8. (a) Painted altar MT-4/011; (b) unpainted altar MT-4/014.

object, made of pottery, with this motif painted two times in red-brown paint on a creamy surface. All three fragments may date to the beginning of Iron Age II (van der Kooij and Ibrahim 1989: 52, 92-93). The motif also appears on shallow saucers where black lines divide the interior, red-slipped surface into four wedges (Daviau, in press a: fig. 3:11) ${ }^{20}$ The difference here is that all the wedge-shaped areas are red slipped, whereas on the altar two red wedges alternate with two black ones.

There is only one painted register of two parallel red lines (but empty of triangles) preserved on

\footnotetext{
${ }^{20} \mathrm{~A}$ pillar figurine from Jerusalem holds a disc, divided into quarters by four pairs of black lines with a single red line framed by each pair.
}

one other face of the altar. This may be the result of the altar's position within the collapsed debris and the exposure of the other faces to moisture. At the same time, it is also possible that there was originally only one side, painted in full, that faced front. This seems reasonable, since the preserved decoration is on the side that is directly below a cupshaped depression on the upper surface of the altar (fig. 9a).

The upper surface $(33.0 \times 37.0 \mathrm{~cm})$ is surrounded by a rim or border that varies in width from 4.3 to $6.0 \mathrm{~cm}$. In the central space, three areas can be distinguished (fig. 9a). The larger area, in the back, comprises about half of the upper surface; it is relatively flat and in good condition. In the other half, at the front, there are two distinct areas. One consists of a depression or sump, $10.0 \mathrm{~cm}$ deep and 9.5$11.0 \mathrm{~cm}$ in diameter. The second area, comprising about one quarter of the upper surface, is pitted and slopes gently to a hole (some $1.0-1.5 \mathrm{~cm}$ in diameter) that pierces the rim of the sump on the diagonal, so that liquid could drain into the depression.

The Unpainted Altar (MT-4/014; fig. 8b). A second, somewhat smaller altar $(0.50-0.55 \mathrm{~m}$ high) of similar style was unpainted. Also carved from a single block of limestone, the shaft of Altar MT-4/ 014 was hammer dressed, without polishing. The sides of the shaft are not quite vertical and bulge slightly. The top of the shaft is in the range of 19.5$20.5 \mathrm{~cm}$, and the base is $20.0-20.7 \mathrm{~cm}$; the height of the shaft is $42.0 \mathrm{~cm}$. At this point, the rim flares out to about $2.9 \mathrm{~cm}$ beyond the sides of the shaft, forming a T-shaped altar. The upper surface of the rim has a margin of about $4.0 \mathrm{~cm}$, although exact measurements of all four sides are not possible because of the broken condition of this altar. The margin surrounds a central depression, roughly $2.0 \mathrm{~cm}$ deep and $18.0 \times 19.0 \mathrm{~cm}$ square. What is still visible on the upper surface of this depression is a layer of soot and a certain amount of flaking of the stone itself, which suggests damage caused by burning.

The Tall, Conical Altar (MT-4/015; fig. 10a, 10b). The third altar is conical in shape, stands $0.96 \mathrm{~m}$ tall, and consists of five segments, each one separated by a row of pendant petals that were originally painted alternately black and red. On top is a cup-shaped depression stained with soot. The uppermost, vertical shaft is painted with a black and red triangular pattern on the front, and a stylized palm tree on the side. A label on the back, adjacent to the palm tree, identifies 


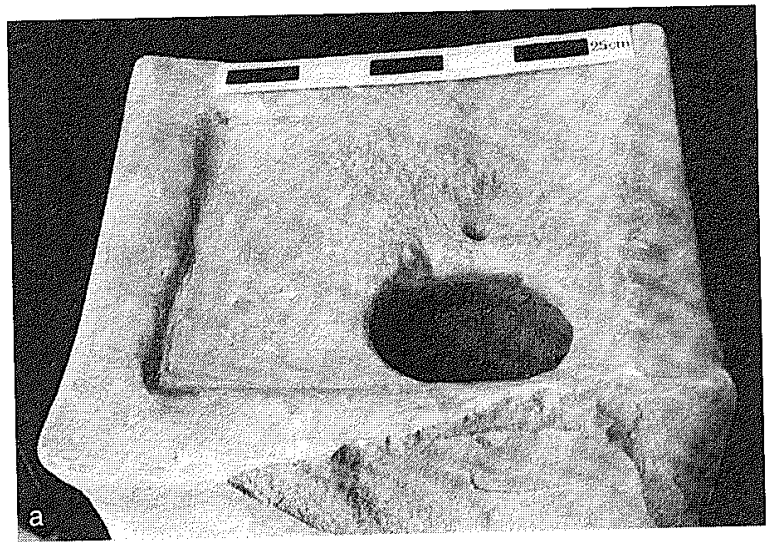

Fig. 9. (a) Painted altar MT-4/011, upper surface; (b) shaft with moldings and panels.

this object as an incense altar and names the maker and the owner. The text is written in a script and dialect related to those of the Mesha materials, but by no means identical; it reads mqtr 'rs's' 'lsm $\mid$ lysp bt ' $w t^{21}$ ("the incense altar that Elishama made for YSP, the daughter of 'WT"). In view of its association with two other altars, each with different characteristics, this label is of great value in identifying the precise function of this conical altar.

Style and Function. Although they are rare in Transjordan, ${ }^{22}$ limestone altars, frequently identified as incense altars, are known from several sites in Cisjordan. The largest group is from the Philistine site of Tel Miqne-Ekron, where at least 12 altars of various shapes and sizes were recovered from Iron Age contexts (Gitin 1989). For the most part, the Tel Miqne altars share much in common with the later, Persian period altars known from Lachish (Tufnell 1953: pl. 68) ${ }^{23}$ and Tall es-Sa ${ }^{c}$ idiya (Prit-

\footnotetext{
${ }^{21}$ Elod Takats (Debrecen, Hungary), a member of the 1999 field team excavating in Sanctuary 149, was the first to recognize the word mqtr. For a full analysis of the label's script, see Dion and Daviau (2000).

${ }^{22}$ Standing stone altars appear in Nabataean and early Roman period contexts. One such sandstone altar (FS3.04A) from Petra stands $1.14 \mathrm{~m}$ high and retains vestigial horns carved on two sides of the altar proper. A shallow depression in the upper surface led the excavator to identify this altar as an incense altar and as a fire altar (Fiema in press: 28, figs. 36-37). Palmyrene altars with vestigial horns are a common type (Galling 1925: pl. 12:17, 19, 27-28).

${ }^{23}$ The altars at Lachish were classified as "tapered stands, cuboid stands, incense stands, offering tables and horned altars" (Tufnell 1953: 383-84). Only the top of one cuboid stand was related to the burning of incense on
}

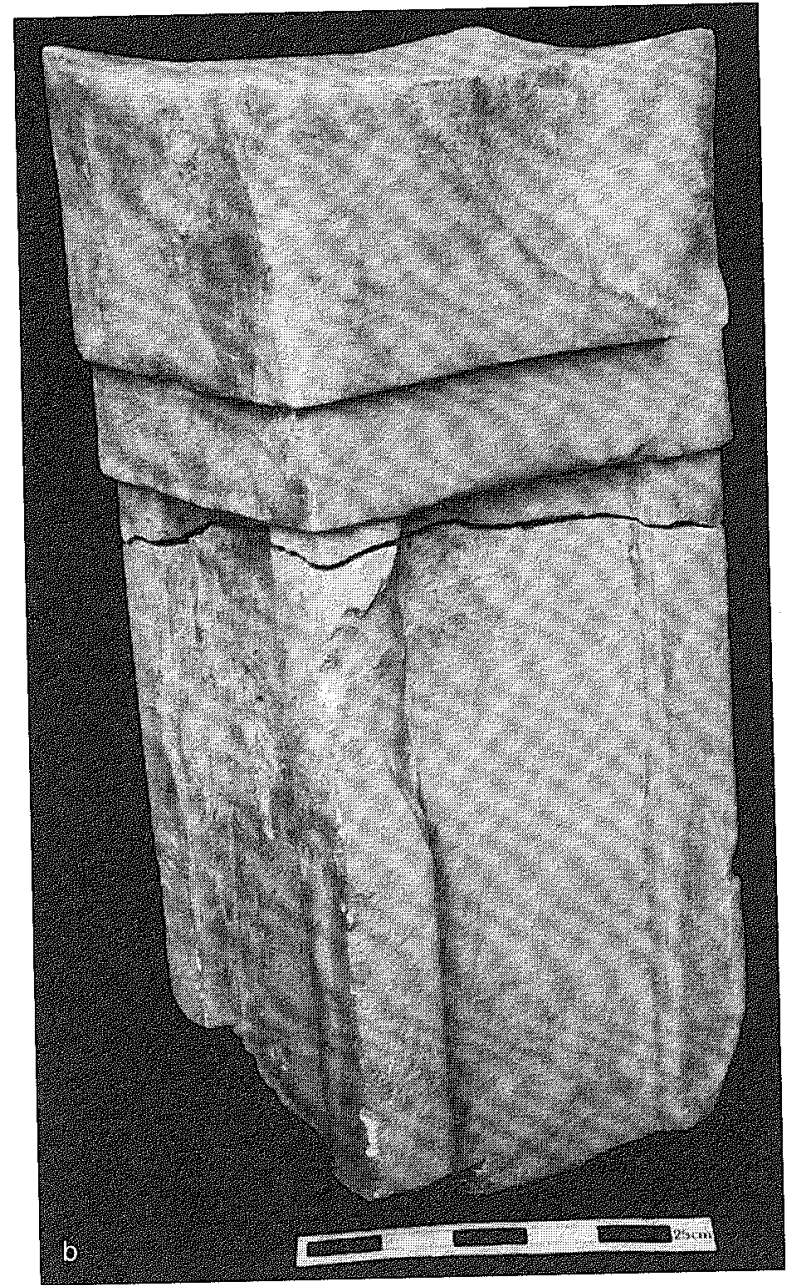

chard 1972). At Lachish, where excavators found more than 200 limestone altars in three separate caches (Tufnell 1953: 383, pl. 8:5-6), none were attributed to the Iron Age, although like those from Tel Miqne, the Lachish altars range in size from $0.12-0.85 \mathrm{~m}$ in height. ${ }^{24}$

Among unpainted altars, the T-shaped shaft altars from Megiddo (May 1935: pl. 12) share certain

the basis of the burn marks on its upper surface. All other stands or altars showed no evidence of burning.

${ }^{24}$ That small, handheld altars were already in use at Khirbat al-Mudayna during the Iron Age is seen from the presence of a miniature limestone altar (MT-2/265), cylindrical in shape, that was found in the upper-storey collapse within Gate Room 152. At the same time, it is important to distinguish between the small cuboid altars and the tall free-standing ones. Just such a distinction is made by Zwickel, who labeled the small cuboid altars "Räucherkästchen" and the larger free-standing altars "Räucheraltäre" (1990: 62, 110). 

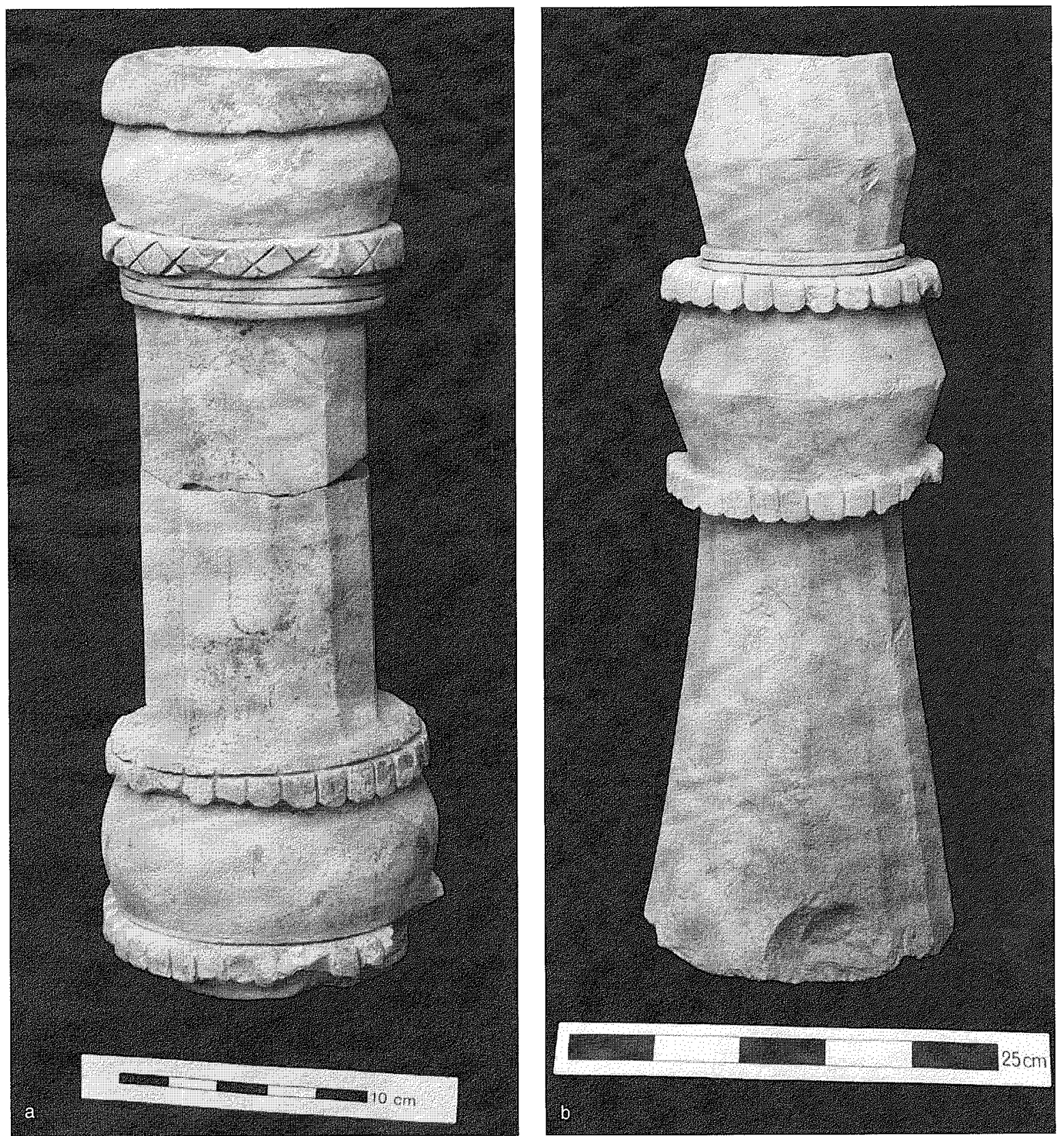

Fig. 10. (a) Inscribed altar MT-4/015, upper half; (b) Altar MT-4/015, base.

similarities with Altar MT-4/014, although these typically have horns at each corner and are somewhat smaller, except for Altar M 2984 which has a maximum height of $0.68 \mathrm{~m}$. These altars have a quadrangular shaft, a horizontal band below the rim, and a rim that protrudes beyond the edges of the shaft. Altar MT-4/014 is also T-shaped, although the rim is broken and only two corners can be restored.
Even in its present condition, it is clear that Altar MT-4/014 is simple in design; it did not have horns or a horizontal band.

Exact parallels for the altars in Building 149 are rare, especially for the two painted altars. What is lacking from the Megiddo examples are the vertical corner moldings and the lower rim section seen on Altar MT-4/011; instead, on certain examples, there 
is a protruding horizontal band or ring that marks the division between the upper and lower parts of the altar. The rim of Megiddo altar M 2984 dips gently, although more deeply than Altar MT-4/011, from one corner to another. In the other instances where horns are represented (e.g., Megiddo altars M 2983, M 5331, and M 2982), they stand vertically above the upper surface or rim of the altar. At the same time, a group from Megiddo-consisting of two limestone horned altars (a729, a730); a tall (about $0.55 \mathrm{~m}$ ), cylindrical limestone altar (a728); and a second, broken altar or stand (a727) from the corner of Courtyard 2081 (Loud 1948: fig. 102)-serves as a good model for the cultic assemblage in Building 149 at Khirbat al-Mudayna. In this case, there are two squat, shaft altars, one larger than the other, that both have low or truncated horns and are square on top (a729, a730). The smaller of these (a729) has two square knobs, one on each front corner of the shaft below the horizontal band (Loud 1948: pl. 254:2).

Stylized pendant petals and incised crossed lines on the tall conical altar (MT-4/015) are motifs that appear below the bowl on cylindrical Altar a728 from Megiddo (Loud 1948: pl. 254:4). So too, painted limestone is not unusual at Megiddo; both Altar a728 and the limestone base of a second, composite altar $(\mathrm{a} 727)^{25}$ are described as having painted decoration (Loud 1948: pl. 254:3-4). An even more elaborate example is a broken Proto-Aeolic capital from Megiddo. In this case, the capital is painted red, blue, black, and white on its outer face. In addition, there is a checkerboard pattern in red, black, and white preserved on one end (Loud 1948: pl. 270:1).

More common examples of artifacts with pendant petals are the ceramic stands that supported a bowl, possibly used to burn incense, ${ }^{26}$ at least such was the assumption of Aharoni (1975:26) in his description of the bowl with petals (Aharoni 1975: pl. 43:1)

\footnotetext{
${ }^{25}$ Loud (1948: pl. 254) describes the cylindrical altars as "cultic stands" because these altars have, at the top, a bowl-like depression. In this respect, they are like ceramic cultic stands that support a bowl (Loud 1948: pl. 148:3). In view of the fact that limestone cylindrical "stands" can sustain burnt offerings, comparable to the squat, square-topped altars, such objects are identified in this study as "altars," and the term "stand" is reserved for ceramic artifacts

${ }^{26}$ Such stands, sometimes in the shape of pedestalfooted chalices, appear at several sites in Palestine includ ing Beth Shemesh (Grant 1932: pl. 35:28).
}

from Sanctuary 49 at Lachish. A good parallel is the ceramic stand and bowl from Megiddo (May 1935: pl. 20:P6056), as well as a painted limestone altar reported by Schumacher (May 1935: fig. 6). Petals present on a ceramic tripod cup (V358) from Tall Jawa (Jordan) are painted with black lines crossed on an angle by whitewash (TJE54.84.1014; Daviau, in press a: fig. 1:6). Macalister (1912: fig. 460) identified pendant knobs decorated with red chevrons as a lotus leaf motif. This pattern, seen on decorated chalices from Megiddo (Lamon and Shipton 1939: pl. 33:15, 17), also appears on six chalices (Gitin 1993: fig. 5:b) found in the Philistine temple at Tel Miqne-Ekron. A stone scepter from Hama (Fugmann 1958: fig. 325:8A264) and a bronze scepter from Tel Dan (Biran 1989: 29) are also decorated with pendant petals, as are Phoenician stone and faience "pyxides" (Barag 1996). ${ }^{27}$ Although this style may have had its origin in Egyptian architectural design, which would account for its wide distribution, the use of such stands in Assyria is evident from their depiction on reliefs. ${ }^{28}$ The "denticulate" pattern that is seen on various vessel types at Horvat Qitmit (Freud and Beit-Arieh 1995: figs. $4.12: 32,15: 3-5,17: 33-37)$, and on a cup sherd (WT-13-97/818) from Wadi ath-Thamad Shrine Site WT-13 (Daviau, in press c) may be a variant of this design.

May (1935: pl. 20) suggested that the burn marks in the bowl of Megiddo Stand P6056 may have been "accidental." 29 The function of the bowl then remains a mystery; was it used for liquid libations as depicted on various seals (Galling 1925: pl. 4:18ab), or to contain food offerings? In fact both uses are possible, although it is clear from textual evidence that incense was used in the domestic cult (van der

\footnotetext{
${ }^{27}$ Pendant petals are also represented in architecturee.g., on the balustrade from Ramat Rahel (Aharoni 1964: pl. 48:1-2) - and on various carved ivory inlays, such as the woman at the window (for several examples, see Beach 1993).

${ }^{28}$ The depiction of stands with pendant petals appears in a variety of settings. Two such stands appear in the scene of Ashurbanipal feasting with his wife; Lohmann (1925: 49) uses this relief as an example of profane use of such altars.

${ }^{29}$ The same can be said for so-called perforated incense cups found in Transjordan because the interior of the cup is usually clean; it is not stained with either soot or with the residue of frankincense. For a discussion of these cups in the cult, see Daviau, in press a.
} 
Toorn 1994: 45) in Babylonia. At the same time, it remains unclear whether resin as well as aromatic woods were used, since one can hardly imagine poor villagers using such a rare commodity in view of its great value. The same cannot be said for temples or shrines where the use of incense, including frankincense, is supported by textual evidence. ${ }^{30}$ According to Finkelstein $(1988 ; 1992)$, there is evidence for the incense trade in the Iron Age, although Bienkowski (1992: n. 7) claims that such trade is not archaeologically attested to before the seventh century B.C. Even Assyrian sources do not mention incense in connection with the Arab trade, although they mention all kinds of spices. It is important to note, however, that the evidence for burning on the altars themselves is often lacking. ${ }^{31}$

In his study of the altars from Tel Miqne-Ekron, Gitin (1989: 58-59) argues that the number of altars now known from various sites in Israel, Judah, and Philistia makes it certain that incense altars were part of the Iron Age cult. While it is clear that altars were part of the cult, it is not clear that the block and shaft altars with their large upper depressions were used for incense. In fact, Gitin includes in his typology the altars from Arad which were shown to have "burnt fat residue" (1989: table 1) ${ }^{32}$ rather than resin on their upper surfaces. What seems clear from the altars found at Khirbat al-Mudayna is that there was a certain style of altar that was used for incense, namely the inscribed conical altar (MT-4/015) with its small bowl-size depression. The function of the

\footnotetext{
${ }^{30}$ A recipe for "incense" appears in Exod 30:34-36. Here frankincense is cited for use in equal parts with other ingredients. We can then suppose that repeated burning of such a mixture would leave a distinctive residue on the container or altar. In the case of tripod cups, it is peculiar that there is no evidence of burnt residue in the small perforations through the sides of the vessel. Surely the burning of such substances would block the holes over time.

${ }^{31}$ This is also the situation in regard to Palmyrene altars; in his description of a previously unpublished altar, Puech (in press) attributes its pristine condition to the fact that it was exposed to water for a long time, with the result that all traces of soot have completely disappeared. If there was soot originally, it is somewhat surprising that there is no evidence remaining in view of the fact that there were traces of paint still preserved in the depths of the inscribed letters of the inscription.

${ }^{32}$ In his preliminary report, Aharoni (1967: 247, n. 29) cites the results of analysis that indicated that the substance was "animal fat."
}

shaft-style altars is less certain because of the large size of the upper depression (Altar MT-4/014) that suggests another, less valuable offering such as animal $\mathrm{fat}^{33}$ or vegetal material. ${ }^{34}$ In the case of Altar MT-4/011, the drain hole and sump clearly point to the offering of libations.

\section{Other Artifacts}

Also present in the debris immediately north of Altar MT-4/011 were two artifacts (MT-4/012 = A18.20.391; MT-4/013 = A18:20.392) cut from soft limestone in the shape of large pegs or mushroomshaped stoppers, each with a large head and thick stem (fig. 11:1-2). The larger of the two objects (MT-4/012) is more irregular in shape, and the tool marks of the maker are still evident on the head and on the faceted stem. In contrast, the second object (MT-4/013) has been carefully finished, especially on the sides of the head and on the shaft of the stem. Because there were no storejars preserved in the temple, the prima facie function of such objects, namely their use as stoppers, cannot be accepted without question. ${ }^{35}$ The head of each peg is in the range of $10.5-12.0 \mathrm{~cm}$, and the stems measure $9.5-11.0 \mathrm{~cm}$ in length. Although the exact purpose of these two pegs remains a puzzle, their association with the altars is reasonable, given the juxtaposition of these finds 36 and the fact that they were carved from limestone similar in quality to the altars.

\footnotetext{
${ }^{33}$ The presence of animal bones and zoomorphic clay figurines in Courtyard 150, adjacent to Sanctuary 149, lends credence to this suggestion, although further analysis of the bones and of the courtyard is needed.

${ }^{34}$ Even more unlikely is the suggestion of Haak (1992: 166) that the large Beer-sheba horned altar was used for incense even though it retains no evidence of burning!

${ }^{35}$ Stoppers of similar shape are reported by Bienkowski (1995: fig. 9.24:1-2) in his study of the Edomite site of Tawilan. Another example, from Lachish (Tufnell 1953: pl. 64:4), has a head in the same size range but has a short $(2.50 \mathrm{~cm}$ ), thick stem (about $7.00-7.35 \mathrm{~cm}$ ), as opposed to stems $9.50-11.00 \mathrm{~cm}$ in length and $5.50-5.60 \mathrm{~cm}$ in diameter.

${ }^{36}$ Inscribed clay cones that recorded building projects were installed in the walls of buildings in Assyria throughout the Late Bronze and Iron Ages. The cones from Assur, called sikkatu (CAD S: 247-51), were often painted and inscribed (Donbaz and Grayson 1984: 1-3). Our thanks to Drs. Douglas Frayne and Grant Frame of the Royal Inscriptions of Mesopotamia Project, University of Toronto, for this information.
} 

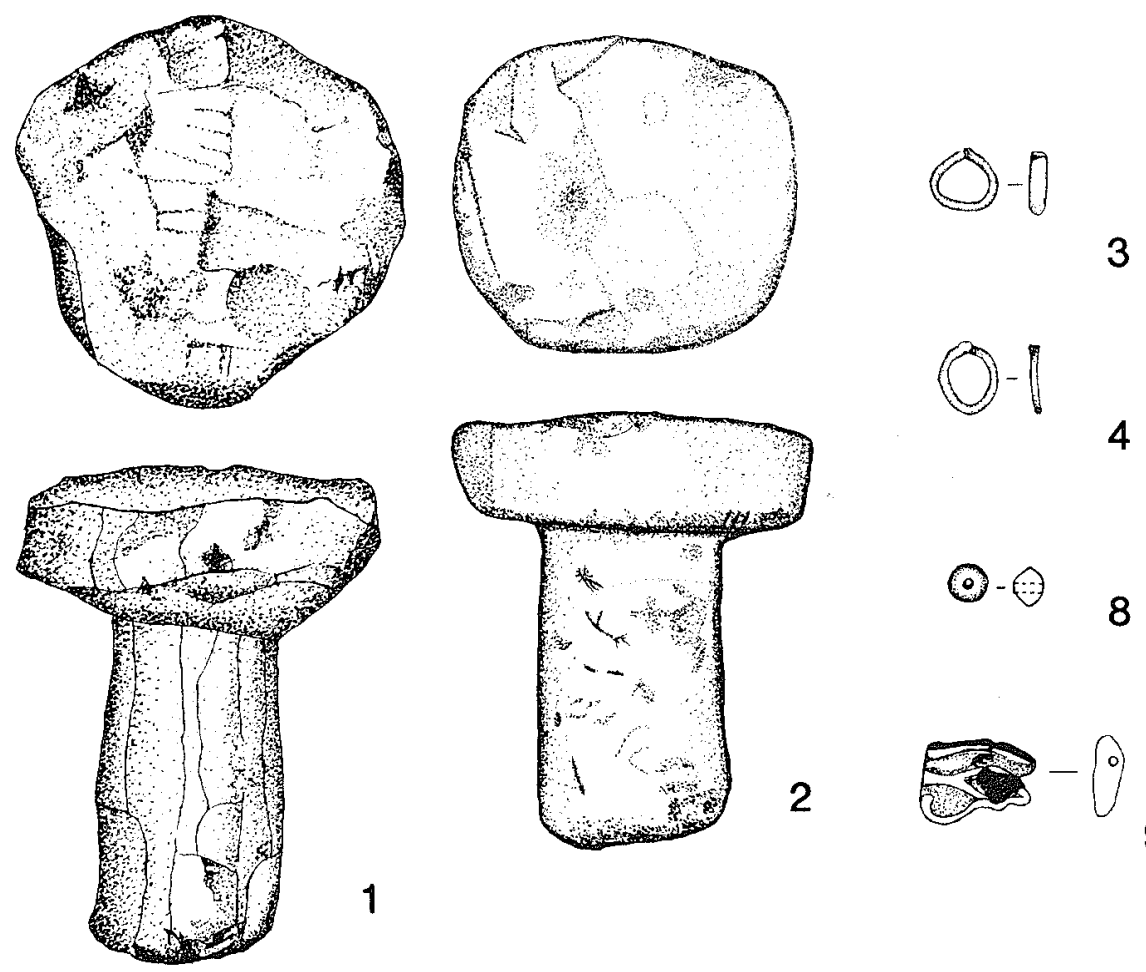

3

4

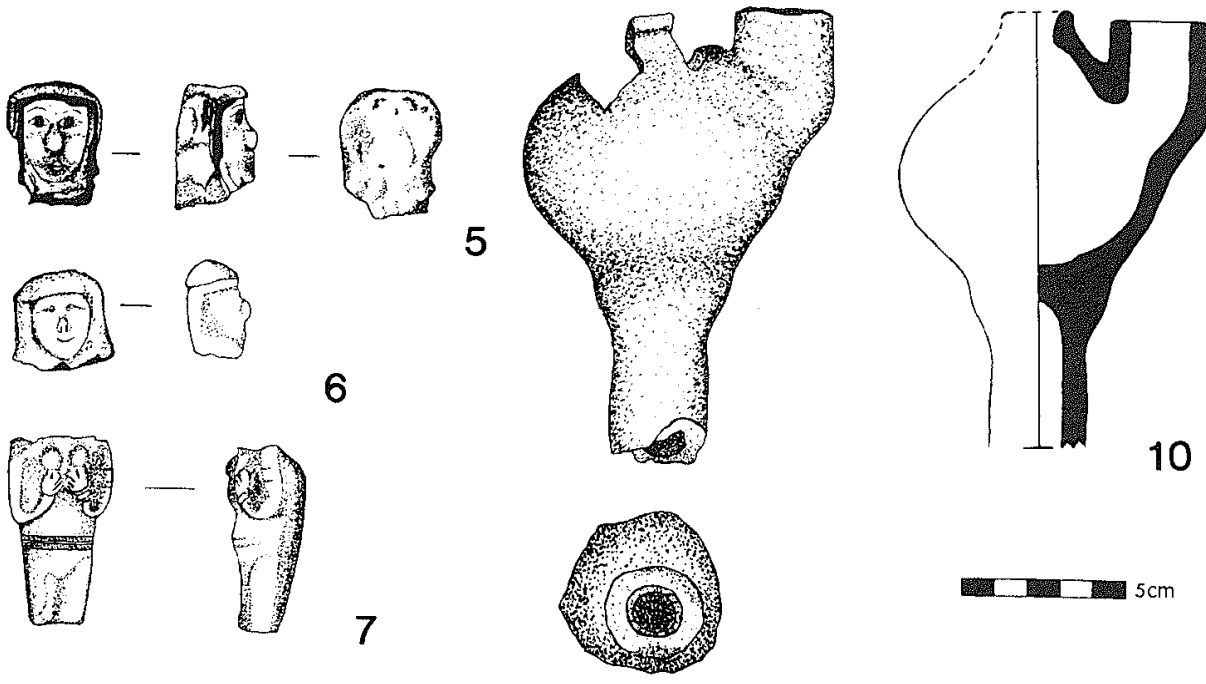

Fig. 11. Limestone pegs (1-2); bronze rings (3-4); ceramic figurines (5-7); bead (8); Wadjet-eye amulet (9); and spouted vessel (10).

In the soil layer (A27:1) piled up against Inner Casemate Wall 2002, to the east and north of the altars, were two bronze rings $(\mathrm{MT}-4 / 023=567$, fig. 11:3; MT-4/006 $=487$, fig. 11:4), the ceramic head of a figurine (MT-4/021 $=565$; fig. 11:5) that depicts a female with painted eyes, lips, and hair, a murex shell (MT-507), and a limestone ball or slingstone (MT-517). Embedded in the destroyed surface and in its makeup was a second murex shell (MT-556) and a large bead (MT-4/010). ${ }^{37}$

In the central part of Room 108, to the west of the altars, finds were even fewer. Another female figurine head (MT-4/004; fig. 11:6) and a fragment of a

\footnotetext{
${ }^{37}$ For the use of shells as votive offerings in temple contexts, see Reese 1988.
} 
stone bowl rim (MT-522) were located in the accumulated debris. These finds were above a lamp (MT-4/019 = V104), which was alone on the floor surface except for a small limestone ball or slingstone (MT-526) and a female figurine torso (MT-4/ 022; fig. 11:7) without head or feet. ${ }^{38} \mathrm{~A}$ spouted vessel with a pedestal base (V122; fig. 11:10) must also have served a cultic purpose, because of its unusual shape. The fact that no complete figurines were present in the temple is consonant with the paucity of small finds and pottery present on the floor and in the pit. This emptiness suggests deliberate removal of all portable sanctuary furnishings at the time of the final attack on the town, which resulted in the burning of the North Gate (B100). The altars may have continued in use; in any event, they are extremely heavy, even in the pieces in which they were found.

Certain artifacts that were probably part of the sanctuary assemblage were buried in deep debris layers, east of Podium Stone 108b, which had collapsed into a lower level alleyway(?) adjacent to Inner Casemate Wall 2002. Of special note are a faience bead (MT-4/009; fig. 11:8) and a Wadjet eye (MT-4/020; fig. 11:9), with a faience glaze (5Y 6/3, pale olive). The amulet represents the right eye, and the pupil and eyebrow are painted black. The best parallels in terms of size and direction of the eye are a number of amulets from Megiddo, assigned to Stratum V (Lamon and Shipton 1939: pl. 75:20), Stratum IV (1939: pl. 75:17), and Stratum III (1939: pl. 75:4).

\section{The Ceramic Remains}

The best preserved ceramic finds consist of five lamps, three intact, one almost complete lamp, and one base. The largest $(11.5 \mathrm{~cm}$ in diameter) and most complete lamp (MT 4/019 = V104; fig. 12:1) has a Judaean style, ${ }^{39}$ stepped base, and clay fabric that is unique for the Mudayna area. ${ }^{40}$ Although within the

\footnotetext{
${ }^{38}$ The position of the hands below, but not covering or supporting, the small breasts is similar to that of a broken figurine from Megiddo (M 5376; May 1935: pl. 28). For a discussion of the Jerusalem figurines published by Holland, see Steiner 1997.

${ }^{39}$ This lamp form also occurs outside Judaea (e.g., Samaria [Crowfoot 1957: fig. 27:4]), although the remaining lamps illustrated for Iron Age II (Crowfoot 1957: fig. $27: 1-3)$ are shallow, with a thin base.

${ }^{40} \mathrm{~S}$. Feltham prepared the final inked drawings of all ceramic vessels and sherds.
}

diameter range of lamps from Jerusalem (10.0-18.0 cm; Franken and Steiner 1990: 103, fig. 6-13:3-4; Eshel and Prag 1995: figs. 8:14-16, 32:8), there is no evidence at present to reveal where this lamp was made. A group of lamps in the Royal Ontario $\mathrm{Mu}$ seum, supposedly from Beth Shemesh, ${ }^{41}$ appear to have the same fabric and coloring as V104; future technological research may clarify its origin. Other lamps, formed of local clay, also have thick bases (V105, V118; figs. 12:2-3), ${ }^{42}$ although in certain examples (V106, V119) these lamps have a disc base, rather than the stepped base, suggesting a date in the late Iron Age II (late eighth-seventh century). Lamps with the same thickened base were present in significant quantities at Lachish (43 examples of Type 152; 76 lamps of Type 153; Tufnell 1953: pl. $83: 149,152-53) .{ }^{43}$ Other parallels for lamps with a thick base occur at Lachish in Stratum II (Aharoni 1975: pl. 48:2-4), at Beth Shemesh (Grant 1932: pl. 45:40-42), and at Arad, Stratum VII (Herzog et al. 1984: fig. 25:14). ${ }^{44}$ Examples from Hazor (Yadin

\footnotetext{
${ }^{41}$ These lamps (GA 51, 53, 59, 63, 87, 97), purchased in Jerusalem around 1909 by C. T. Currelly from Vester \& Company, were all attributed to Beth Shemesh. Another lamp with a thick base and reddish fabric (GA 57), purchased at the same time, was from ${ }^{\mathrm{C}} \mathrm{En}$ Gedi.

${ }^{42}$ Vessels V105 and V106 are clearly local products, not only in fabric but also in the unfinished appearance of the base, a characteristic seen both at Khirbat al-Mudayna and at Shrine Site WT-13. The identification of vessels as being of local production is based on a study of 2,830 sherds from a surface survey conducted in 1995. At that time Daviau identified six fabric types. All of the sherds were formed of clay with small inclusions, completely oxidized during firing, and in the color range of pale yellow (2.5YR 8/3) to light gray (10YR 7/2). The large number of sherds of each of these ware types suggests that this is the result of local production.

${ }^{43}$ Lamps with a thick, stepped base are not represented in the corpora studied by Dornemann (1983: figs. 31, 42). At Dhibân, rare examples were present among the saucer lamps in Tombs J5 (1 out of 16; Tushingham 1972: fig. 15:13); J6 ( 1 of $14 ; 1972$ : fig. $20: 5$ ) and $\mathrm{J} 7$ ( 1 of $9 ; 1972$ : fig. 23:18). In Ammon, the form of late Iron Age II/early Persian period lamps is that of a shallow saucer, with a thin disc base (Low 1991: figs. 8.12:13; 8.17:30; 8.22:1517). Parallels cited here are not intended to be exhaustive; they are given as examples only.

${ }^{44}$ In the verbal description, item 14 is identified as a "juglet"; one can only assume that the ware description does in fact refer to the lamp shown in fig. 25:14.
} 

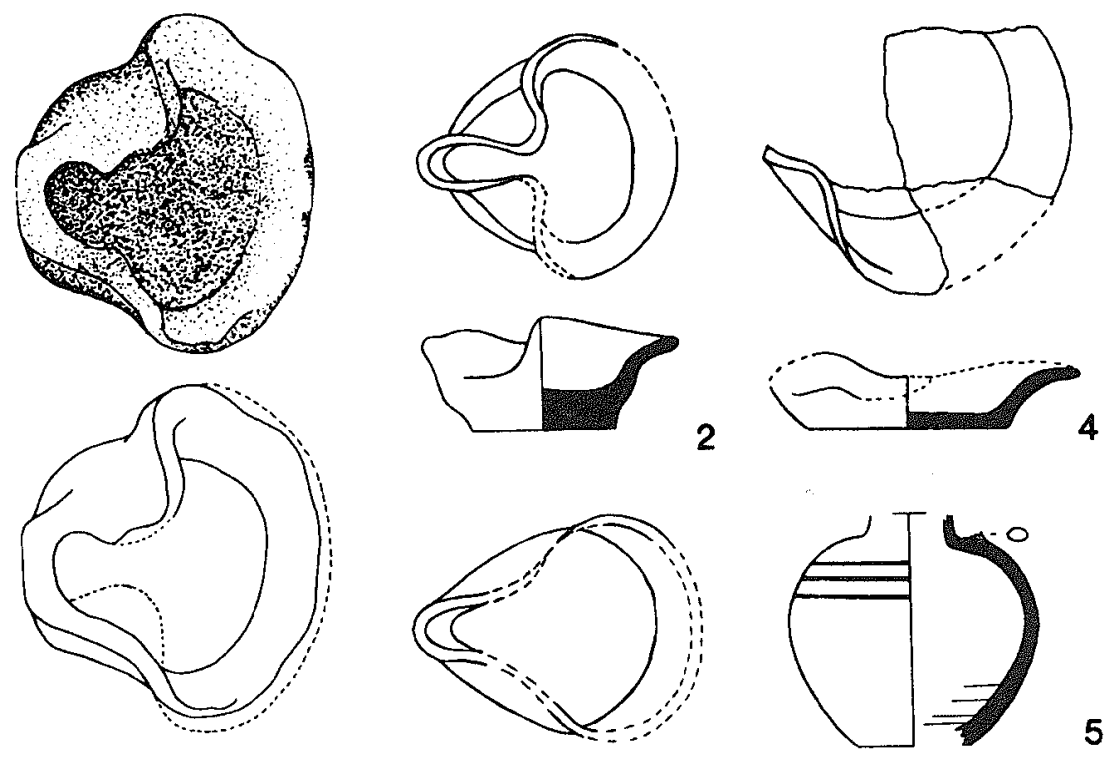

5
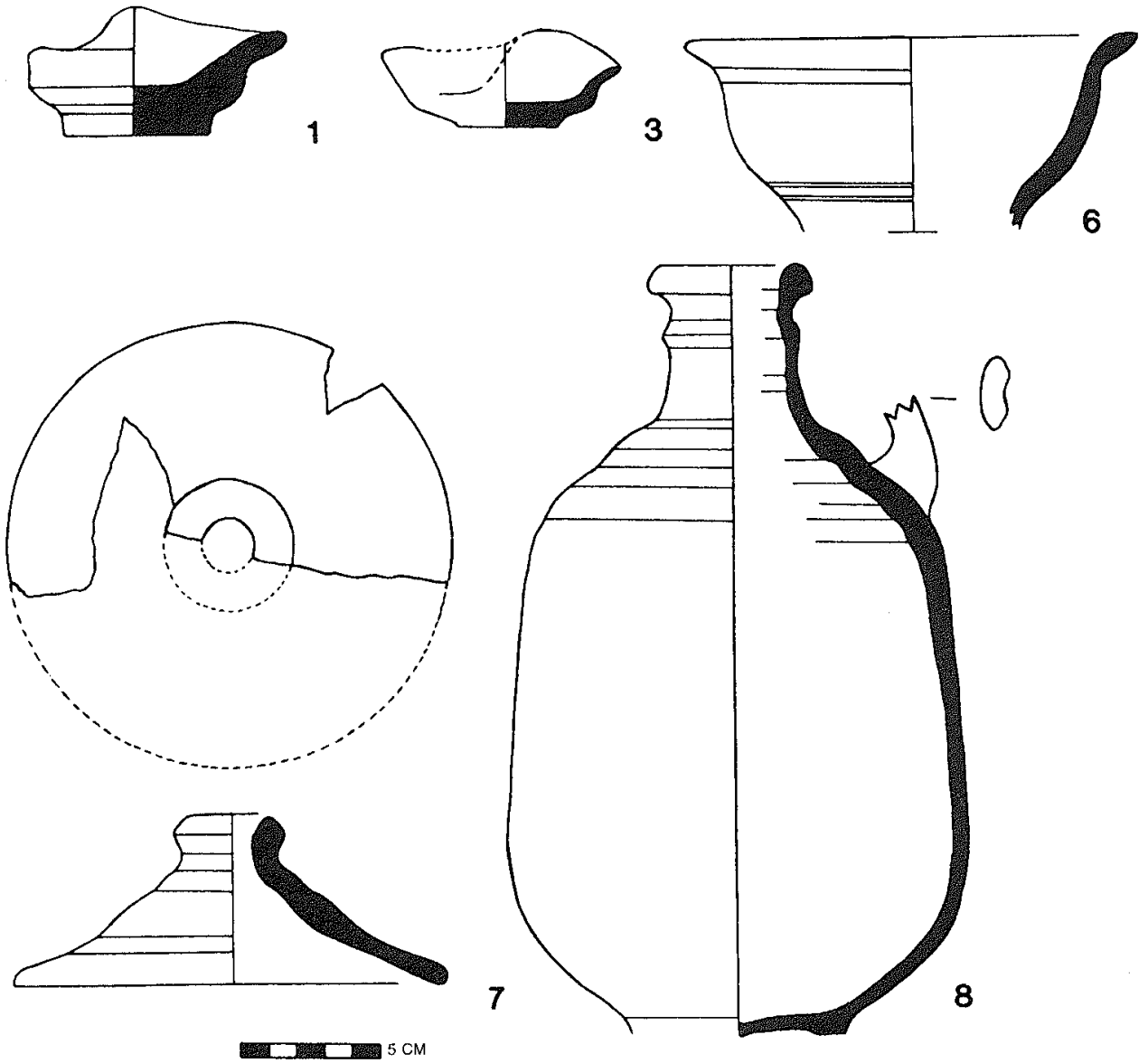

Fig. 12. Lamps (1-4); white-slipped vessel, possibly a chalice (5); possible funnel (6); juglet (7); and decanter $(8)$. 

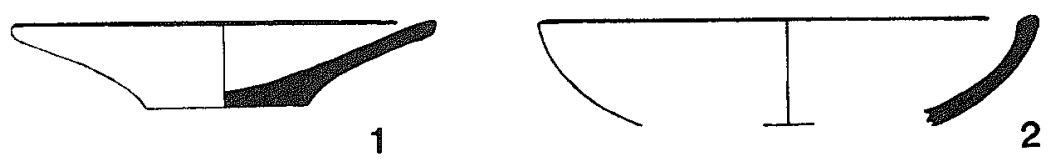

2

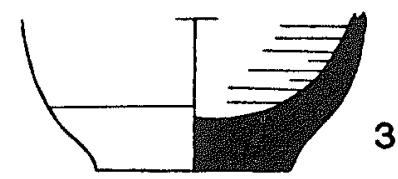

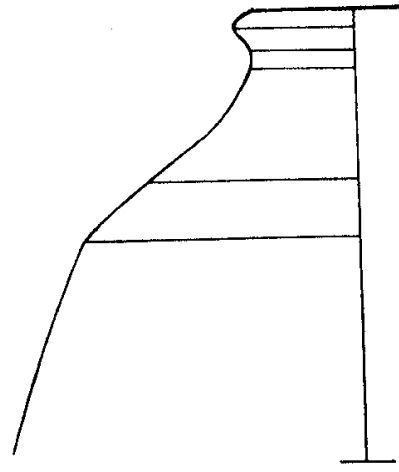

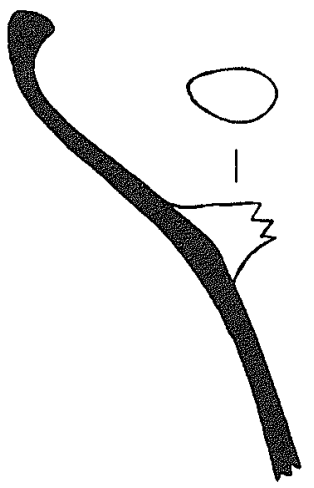

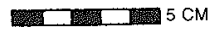

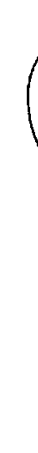

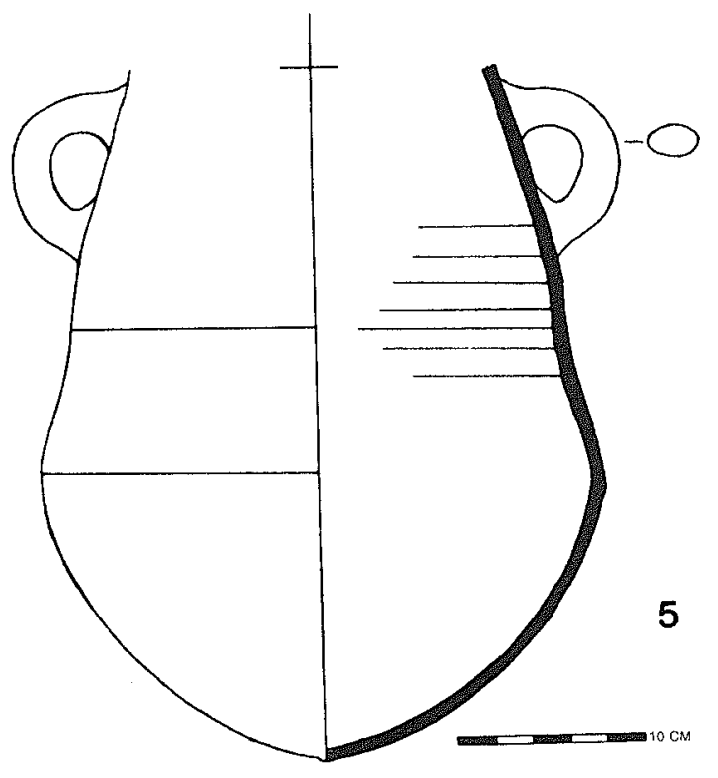

Fig. 13. Shallow bowls (1-2); small jug (3); and storejars (4-5).

et al. 1961: pl. 232:9-10) occur in the same stratum (VA) with shallow saucer lamps.

Other recognizable vessel types include a whiteslipped chalice or funnel (V110; fig. 12:6), a second funnel or lid (V121; fig. 12:7), one (V111) or more jugs, a painted juglet (V107; fig. 12:5), and a Judaeanstyle decanter (V120; fig. 12:8). Partial remains of a saucer bowl (V123; fig. 13:1), a shallow bowl (V109; fig. 13:2), a jug (V114; fig. 13:3), and four jars (including V108, fig. 13:4; V116, fig. 13:5) were recovered from the pit $(108 \mathrm{a}=\mathrm{A} 17: 64)$ in the center of Room 108; none of the vessels could be restored, although sherds from these same vessels were also found in the temple proper. One jar (V115) clearly had four handles, and a second jar (V116) with two handles was restored shoulder to base (fig. 13:5). Here, too, in the pit, the evidence suggests the hasty gathering together of items used in the sanctuary and their disposal in the pit that was quickly but completely sealed when the town was under attack. The sanctuary could have continued in use for religious purposes, because the altars were still in place. The evidence of smithing suggests that the sanctuary may have served a defensive purpose at the time of the attack on the town. This suggestion is supported by the fact that no metal cultic artifacts were recovered in B149. On the other hand, iron arrowheads were present in the gate complex adjacent to the sanctuary.

\section{The Function of Building 149}

The objects present on the floor and within the overlying debris layers, as well as the architectural plan of this building (with its benches along the side walls and a niche), suggest that this was a small shrine adjacent to the gate. The evidence of the inscribed label and the presence of soot on Altar MT4/015 clearly indicate the burning of incense. In the case of Altar MT-4/014, the soot on its upper surface is also the result of burning. However, it is possible that offerings, such as grain or animal fat and meat, were burnt on this altar, especially in view of the $2000+$ animal bones with cut marks that were recovered from Courtyard 150 . The lack of burn marks on Altar MT-4/011 and the presence of a drain hole and sump point to liquid offerings. 
These altars all appear to have been in position on Stone A18:12, adjacent to Bench 1042 running perpendicular along the south wall. Finds remaining on the floor of Room 108 in front of the altars are insufficient to identify other cultic activities that were performed in the sanctuary.

The use of the benches as shelves to position offerings cannot be substantiated on the basis of the archaeological record owing to the paucity of finds, especially of ceramic vessels. The position of the lamps, on or adjacent to the benches, strongly suggests that they were indeed located on the benches. The niche in the west wall, while suggestive in view of its position, yielded no finds that could reveal its true function.

The location of the round limestone mortar, surrounded by slag, is the clearest indication of an activity area. At the same time, the nature of that activity and the association of the mortar with the small trough do not point directly to a specific craft or industry related to the other activities in the sanctuary. One might suppose that during the attack on the town, weapons were being fashioned, or refashioned, here in this well-protected corner, possibly after the sanctuary had been cleared of all portable sacred objects. This may also account for the presence of a gaming board in the sanctuary, although such boards could also have been used for the purpose of divination (Daviau, in press a). ${ }^{45}$ At this stage in the excavations, it is clear that Sanctuary 149 is of great importance for its altars and its inscription, although the archaeological record for this sanctuary leaves us with many unanswered questions concerning the cultic behavior of the inhabitants of Khirbat al-Mudayna and the deities that they worshipped.

\footnotetext{
${ }^{45}$ It is also possible that the gaming board (MT-4/017) was in secondary use as an anvil in the refashioning of iron arrowheads. Residue on its surface is similar to that in the limestone mortar (MT-4/018).
}

\section{REFERENCES}

Aharoni, Y.

1964 Excavations at Ramat Rahel: Seasons 1961 and 1962. Rome: Centro di Studi Semitici.

1967 Excavations at Tel Arad: Preliminary Report of the Second Season, 1963. Israel Exploration Journal 17: 233-49.

1968 Arad: Its Inscriptions and Temple. Biblical Archaeologist 31: 2-32.

1975 Investigations at Lachish: The Sanctuary and the Residency (Lachish V). Publications of the Institute of Archaeology, Tel Aviv University 4. Tel Aviv: Gateway.

Barag, D.

1996 Early Traditions in Phoenician Stone Vessels of the Eighth-Seventh Centuries BCE. EretzIsrael 25 (Joseph Aviram volume): 82-93 (Hebrew), 90* (English summary).

Beach, E. F.

1993 The Samaria Ivories, Marzeah, and Biblical Text. Biblical Archaeologist 56: 94-104.

Bienkowski, P.

1992 The Beginning of the Iron Age in Southern Jordan: A Framework. Pp. 1-12 in Early Edom and Moab: The Beginning of the Iron Age in Southern Jordan, ed. P. Bienkowski. Sheffield Archaeological Monographs 7. Sheffield: Collis.

1995 The Small Finds. Pp. 79-92 in Excavations at Tawilan in Southern Jordan, by C.-M.
Bennett and P. Bienkowski. British Academy Monographs in Archaeology 8. Oxford: Oxford University.

Biran, A.

1989 Prize Find: Tel Dan Scepter Head-Belonging to Priest or King? Biblical Archaeology Review 15, no. 1: 29-31.

Crowfoot, G. M.

1957 Israelite Pottery, General List. Pp. 134-98 in The Objects from Samaria, by J. W. Crowfoot, G. M. Crowfoot, and K. M. Kenyon. SamariaSebaste 3. London: Palestine Exploration Fund.

Daviau, P. M. M.

1997 Moab's Northern Border: Khirbat al-Mudayna on the Wadi ath-Thamad. Biblical Archaeologist 60: 222-28.

In press a Family Religion: Archaeological Evidence for the Paraphernalia of the Domestic Cult. The World of the Aramaeans: Biblical, Historical and Cultural Studies in Honour of Paul-Eugène Dion, Vol. 2, ed. P. M. M. Daviau, J. W. Wevers, and M. Weigl. JSOT Supplement Series 325. Sheffield: Sheffield Academic.

In press b New Light on Iron Age Religious Iconography: The Evidence from Moab. Studies in the History and Archaeology of Jordan VII. Amman: Department of Antiquities.

In press c Survey and Excavation in Northern Moab. Proceedings of the First International Congress 
on the Archaeology of the Ancient Near East. 2 vols. Rome: Università di Roma "La Sapienza."

Dion, P.-E., and Daviau, P. M. M.

2000 An Inscribed Incense Altar of Iron Age II at Hirbet el-Mudēyine (Jordan). Zeitschrift des Deutschen Palästina-Vereins 116: 1-13.

Donbaz, V., and Grayson, A. K.

1984 Royal Inscriptions on Clay Cones from Ashur now in Istanbul. Royal Inscriptions of Mesopotamia Supplements 1. Toronto: University of Toronto.

Dornemann, R. H.

1983 The Archaeology of the Transjordan in the Bronze and Iron Ages. Milwaukee: Milwaukee Public Museum.

Eshel, I., and Prag, K.

1995 Excavation by K. M. Kenyon in Jerusalem 1961-1967, Vol. 4: The Iron Age Cave Deposits on the South-east Hill and Isolated Burials and Cemeteries Elsewhere. British Academy Monographs in Archaeology 6. Oxford: Oxford University.

Fiema, Z. T.

In press Petra Church Project. American Center of Oriental Research Publication 3. Amman: American Center of Oriental Research.

Finkelstein, I.

1988 Arabian Trade and Socio-Political Conditions in the Negev in the Twelfth-Eleventh Centuries B.C.E. Journal of Near Eastern Studies 47: 241-52.

1992 Horvat Qitmit and the Southern Trade in the Late Iron Age II. Zeitschrift des Deutschen Palästina-Vereins 108: 156-70.

Franken, H. J., and Steiner, M. L.

1990 Excavations in Jerusalem 1961-1967, Vol. 2: The Iron Age Extramural Quarter on the SouthEast Hill. British Academy Monographs in Archaeology 2. Oxford: Oxford University.

Freud, L., and Beit-Arieh, I.

1995 Pottery. Pp. 209-57 in Horvat Qitmit: An Edomite Shrine in the Biblical Negev, ed. I. BeitArieh. Monograph Series of the Institute of Archaeology 11. Tel Aviv: Institute of Archaeology, Tel Aviv University.

Fugmann, E.

1958 Larchitecture des périodes pré-hellénistiques. Hama 2:1. Nationalmuseets Skrifter, Større Beretninger 4 . Copenhagen: Fondation Carlsberg.

Galling, K.

1925 Der Altar in den Kulturen des alten Orients: Eine archäologische Studie. Berlin: Curtius.

Gitin, S.

1989 Incense Altars from Ekron, Israel and Judah: Context and Typology. Eretz-Israel 20 (Yigael Yadin memorial volume): $52 *-67 *$.
1992 New Incense Altars from Ekron: Typology, Context and Function. Eretz-Israel 23 (Avraham Biran volume): $43^{*}-49 *$.

1993 Seventh Century B.C.E. Cultic Elements at Ekron. Pp. 248-58 in Biblical Archaeology Today, 1990: Proceeding of the Second International Congress on Biblical Archaeology, Jerusalem, June-July 1990, eds. A. Biran and J. Aviram. Jerusalem: Israel Exploration Society.

Grant, E.

1932 Ain Shems Excavations, 1928, 1929, 1930, 1931, Part 2. Biblical and Kindred Studies 4. Haverford, PA: Haverford College.

Haak, R. D.

1992 Altar. Pp. 162-67 in Anchor Bible Dictionary, Vol. 1, ed. D. N. Freedman. New York: Doubleday.

Herzog, Z.; Aharoni, M.; Rainey, A. F.; and Moshkovitz, S. 1984 The Israelite Fortress at Arad. Bulletin of the American Schools of Oriental Research 254: $1-34$.

Lamon, R. S., and Shipton, G. M.

1939 Megiddo I: Seasons of 1925-1934, Strata I-V. Oriental Institute Publications 42. Chicago: University of Chicago.

Lohmann, P.

1925 Der Assyrische Altar. Pp. 39-53 in Der Altar in den Kulturen des alten Orients: Eine archäologische Studie, by K. Galling. Berlin: Curtius.

Loud, G.

1948 Megiddo II: Seasons of 1935-1939. 2 vols. Oriental Institute Publications 62. Chicago: University of Chicago.

Low, R. D.

1991 Field F: The Eastern Shelf. Pp. 170-231 in Madaba Plains Project 2: The 1987 Season at Tell el- ${ }^{-}$Umeiri and Vicinity and Subsequent Studies, eds. L. G. Herr, L. T. Geraty, Ø. S. LaBianca, and R. W. Younker. Berrien Springs, MI: Andrews University.

Macalister, R. A. S.

1912 The Excavation of Gezer, 1902-1905 and 1907-1909, Vol. 2. London: Murray.

May, H. G.

1935 Material Remains of the Megiddo Cult. Oriental Institute Publications 26. Chicago: University of Chicago.

Pritchard, J. B.

1972 An Incense Burner from Tell es-Sa idiyeh, Jordan Valley. Pp. 3-17 in Studies on the Ancient Palestinian World: Presented to Professor F. V. Winnett on the Occasion of His Retirement, I July 1971, eds. J. W. Wevers and D. B. Redford. Toronto Semitic Texts and Studies 2. Toronto: University of Toronto. 
Puech, E.

In press Un nouvel autel à encens de Palmyre. The World of the Aramaeans: Biblical, Historical, and Cultural Studies in Honour of Paul-Eugène Dion, Vol. 2, ed. P. M. M. Daviau, J. W. Wevers, and M. Weigl. JSOT Supplement Series 325. Sheffield: JSOT.

Reese, D. S.

1988 Recent Invertebrates as Votive Gifts. Pp. 26065 in The Egyptian Mining Temple at Timna, by B. Rothenberg. Researches in the Arabah 1, 1959-1984. London: Institute of ArchaeoMetallurgical Studies.

Steiner, M. L.

1997 Two Popular Cult Sites of Ancient Palestine: Cave 1 in Jerusalem and E 207 in Samaria. Scandinavian Journal of the Old Testament 11: 16-28.

Tufnell, O.

1953 Lachish III: The Iron Age. New York: Oxford University.

Tushingham, A. D.

1972 The Excavations at Dibon (Dhibân) in Moab. The Third Campaign 1952-53. Annual of the
American Schools of Oriental Research 40. Cambridge, MA: American Schools of Oriental Research.

van der Kooij, G., and Ibrahim, M. M.

1989 Picking up the Threads ... : A Continuing Review of Excavations at Deir Alla, Jordan. Leiden: University of Leiden, Archaeological Centre.

van der Toorn, K.

1994 From Her Cradle to Her Grave: The Role of Religion in the Life of the Israelite and the Babylonian Woman. Biblical Seminar Series 23. Sheffield: JSOT.

Zwickel, W.

1990 Räucherkult und Räuchergeräte: Exegetische und archäologische Studien zum Räucheropfer in Alten Testament. Orbis Biblicus et Orientalis 97. Freiburg, Switzerland: Universitätsverlag.

Yadin, Y.; Aharoni, Y.; Amiran, R.; Dothan, T.; Dothan, M.; Dunayevsky, I.; and Perrot, J.

1961 Hazor III-IV: An Account of the Third and Fourth Seasons of Excavation, 1957-1958: Plates. Jerusalem: Magnes. 